
\title{
25 Research Soure \\ Geochemistry of Street Dust in Tyumen, Russia: Influence of Traffic Load
}

\section{Dmitriy Moskovchenko ( $\nabla$ moskovchenko1965@gmail.com )}

Tyumen State University: Tumenskij gosudarstvennyj universitet https://orcid.org/0000-0001-6338-7669

\section{Roman Pozhitkov}

Tyumenskii gosudarstvennyi universitet: Tumenskij gosudarstvennyj universitet

\section{Dzhamilya Ukarkhanova}

Tyumenskii gosudarstvennyi universitet: Tumenskij gosudarstvennyj universitet

\section{Research Article}

Keywords: Road dust, Trace metals, Major elements, Contamination factor, Enrichment factor and Igeo,

Traffic load, Tyumen City

Posted Date: August 4th, 2021

DOl: https://doi.org/10.21203/rs.3.rs-718462/v1

License: (우 (i) This work is licensed under a Creative Commons Attribution 4.0 International License. Read Full License

Version of Record: A version of this preprint was published at Environmental Science and Pollution Research on January 10th, 2022. See the published version at https://doi.org/10.1007/s11356-021-180130 . 


\section{Abstract}

The article presents the results of studying the composition of road dust in Tyumen, a large city in Western Siberia. On roads with different traffic intensities, 50 dust samples were taken, in which the particle size distribution, $\mathrm{pH}$, and organic carbon content were determined. The content of 62 major and trace elements was studied using atomic emission spectrometry (AES-MS) и inductively coupled plasma spectrometry (ICP-MS). It was revealed that the dust has an alkaline reaction $\mathrm{pH}=7.4-10.2$, low organic carbon content (0.07-2.9\%). The particle size distribution is dominated by particles $\mathrm{PM}=100-250$. The content of small particles ( $P M<2$ and PM2-10) representing the greatest environmental hazard is minimal on roads with an average traffic intensity. Studies have shown that the main road dust pollutants in Tyumen are $\mathrm{Ni}, \mathrm{Sb}, \mathrm{Cr}$, $\mathrm{Zn}, \mathrm{Co}$. The average geoaccumulation index (Igeo) values are ranked as $\mathrm{Ni}(2.2)>\mathrm{Sb}(1.5)>\mathrm{Cr}(1.3)>\mathrm{Zn}$ $(0.4)>\mathrm{Co}(0.4)>\mathrm{Cu}(0.2)$. The contamination evaluation through enrichment factor (EF) calculation showed that road dust is highly enriched in $\mathrm{Ni}$ and significantly in $\mathrm{Cr}$ and $\mathrm{Sb}$. More than $80 \%$ of $\mathrm{Zn}, \mathrm{Co}, \mathrm{Cu}$ and more than $90 \%$ of $\mathrm{Ni}, \mathrm{Sb}, \mathrm{Cr}$ come from anthropogenic sources. By the content of $\mathrm{Ni}$ and $\mathrm{Cr}$, Tyumen surpasses all cities of the Earth where similar studies were carried out. The high Ni content is associated with the composition of local soils and roadways, increased content in vehicle exhaust gases, and abrasion of metal parts. Calculations of the total pollution indices (IPI and Zc) showed that the level of road dust pollution in most of Tyumen's territory is average, moderately hazardous.

\section{Introduction}

Road dust is currently one of the main objects in the study of the ecological state of urbanized areas. Its composition depends on the intensity of erosion of roadside soils, emissions from mobile sources, abrasion of road surfaces and markings, abrasion of tires and brake pads of vehicles, corrosion of their metal parts, traffic patterns and the use of deicing agents (Murakami et al. 2007; Irvine et al. 2009; Nazzal et al. 2013). Dust particles accumulate toxic metals and metalloids (TMM), organic compounds, including polycyclic aromatic hydrocarbons (Chow et al. 1996; Varrica et al. 2003; Denier van de Gon 2013; Amato et al. 2014; Kosheleva et al. 2018). The high concentration of toxic substances in the dust makes it hazardous to human health. Dust microparticles increase the risk of respiratory, cardiovascular and oncological diseases (Tager 2005). Small particles with a diameter $<10 \mu \mathrm{m}$ are most dangerous because they are in the air for a long time, enter the lungs and settle in them (Kjelgaard et al. 2004).

In many cities of Russia, a hazardous environmental situation caused by atmospheric air pollution has been repeatedly noted (Kasimov et al. 2014; Krupnova et al. 2020). However, there are few studies of road dust. The composition of road dust was determined in Moscow (Ladonin, Plyaskina 2009; Vlasov 2015; Kasimov et al. 2019b), cities of the Perm region (Kaigorodov et al. 2009); Chelyabinsk (Krupnova et al. 2020), Alushta (Kasimov et al. 2019a). In Tyumen, 20 samples of road dust were analyzed, as a result of which a conclusion was made about the high content of $\mathrm{Cr}, \mathrm{Ni}$, and $\mathrm{Co}$ (Konstantinova et al. 2020).

We have studied the content of heavy metals and metalloids in 50 samples of Tyumen road dust. The objectives of the presented work are to identify the features of HMM accumulation in road dust, depending on the traffic intensity and the location of other polluting objects, to assess the ratio of natural and 
anthropogenic sources, to evaluate the level of pollution. The present study complements and expands the work of Konstantinova et al. (2020) by: (a) collecting a large number of samples from a wider area around the city of Tyumen (50 sampling sites); (b) measuring the concentrations of other major and trace elements (Al, $\mathrm{Ba}, \mathrm{Cd}, \mathrm{Co}, \mathrm{Cr}, \mathrm{Cu}, \mathrm{Fe}, \mathrm{Mn}, \mathrm{Ni}, \mathrm{Pb}, \mathrm{Sc}, \mathrm{Sr}, \mathrm{Ti}, \mathrm{U}, \mathrm{V}$ and $\mathrm{Zn}$ ) in the road dust; (c) estimates of the ratio of natural and anthropogenic sources of HMMs in road dust.

\section{Materials And Methods}

\section{Study area}

The study was carried out in Tyumen, the largest city in the Tyumen oblast (province), known primarily as a region of the oil production. Tyumen is located in the southwestern part of the West Siberian Plain, in the extreme south of the taiga zone. The climate of Tyumen is cold continental, the average annual air temperature is $+0.9^{\circ} \mathrm{C}$, the amount of precipitation for the year is $480 \mathrm{~mm}$ (Reference Book 1998). Southerly and westerly winds prevail. The rapid development of Tyumen began in the second half of the 20th century after the discovery of numerous oil and gas fields in the north of Western Siberia. In the 1960s the population of Tyumen was about 150 thousand people, at the end of the 1990s it was about 500 thousand, and now it has exceeded 800 thousand people. In Tyumen, there are enterprises of mechanical engineering, instrument making and metalworking, oil refining, production of building materials, energy (combined heat and power plants). Transport streams pass through Tyumen to the northern regions, where oil and gas fields are located. The city operates 385 thousand vehicles, the total length of the road network is $1241 \mathrm{~km}$ (Konstantinova et al. 2019). Emissions from vehicles account for more than $80 \%$ of the gross emissions of pollutants entering the city's atmosphere (Krestyannikova et al. 2015). The traffic load on the roads with the most intensive traffic reaches 8.1 thousand vehicles per hour (Germanova and Kernozhitskaya 2014).

\section{Sampling and laboratory analysis}

Road dust sampling was carried out in June 2020 in dry weather. Roads with different traffic intensities were examined: high ( $>4$ thousand vehicles per hour), moderate (1-4 thousand) and low ( $<1$ thousand). The traffic intensity was determined according to the data (Guseinov, 2000; Germanova and Kernozhitskaya 2014). Roads with low traffic volume are common mainly on the outskirts of Tyumen in low-rise residential area, while traffic intensity is highest in the city center. Samples weighing 200-300 g were taken with a plastic brush and a scoop from the surface of the roadway on test plots $1 \times 1 \mathrm{~m}$ in size, placed in plastic bags and delivered to the laboratory. A total of 50 samples were taken. The location of sampling points is shown in Fig. 1. A detailed description of the sampling sites is presented in Supplementary Materials Table 1.

In the laboratory, the samples were sieved through a sieve with a mesh size of $1 \mathrm{~mm}$ to remove impurities (vegetation residues, debris). Then, the samples were dried slowly using an oven. The $\mathrm{pH}$ value was measured in the samples using a HydroMaster HM-500 ionometer. The organic carbon (OC) content was determined by calcining to constant weight (GOST 23740-2016). The particle size distribution was 
determined by laser diffraction using a Mastersizer 3000 laser particle size analyzer. The content of 54 trace elements ( $\mathrm{Li}, \mathrm{Be}, \mathrm{Sc}, \mathrm{V}, \mathrm{Cr}, \mathrm{Co}, \mathrm{Ni}, \mathrm{Cu}, \mathrm{Zn}, \mathrm{Ga}, \mathrm{As}$, Se, Rb, Sr, Y, Zr, Nb, Mo, Rh, Pd, Ag, Cd, Sn, Sb, Te, Cs, $\mathrm{Ba}, \mathrm{La}, \mathrm{Ce}, \mathrm{Pr}, \mathrm{Nd}, \mathrm{Sm}, \mathrm{Eu}, \mathrm{Gd}, \mathrm{Tb}, \mathrm{Dy}, \mathrm{Ho}, \mathrm{Er}, \mathrm{Tm}, \mathrm{Yb}, \mathrm{Lu}, \mathrm{Hf}, \mathrm{Ta}, \mathrm{W}, \mathrm{Re}, \mathrm{Ir}, \mathrm{Pt}, \mathrm{Au}, \mathrm{Hg}, \mathrm{Tl}, \mathrm{Pb}, \mathrm{Bi}, \mathrm{Th}, \mathrm{U}$ ) and 8 major elements $\left(\mathrm{Na}_{2} \mathrm{O}, \mathrm{MgO}, \mathrm{Al}_{2} \mathrm{O}, \mathrm{P}_{2} \mathrm{O}_{5}, \mathrm{~S}, \mathrm{~K} 2 \mathrm{O}, \mathrm{CaO}, \mathrm{Fe}_{2} \mathrm{O}_{3}\right)$ were measured in road dust samples by using Inductively Coupled Plasma ICP-MS (X-7 Thermo Elemental,USA) and atomic emission method AES-MS (iCAP-6500, Thermo Scientific, USA).

For analysis, portions of samples weighing $100 \mathrm{mg}$ were used. Sample digestion was carried out in an open system. The samples were placed in Teflon beakers (volume $50 \mathrm{ml}$ ), $0.1 \mathrm{ml}$ of a solution containing $8 \mu \mathrm{g} \mathrm{dm}^{-3} 145 \mathrm{Nd}, 61 \mathrm{Dy}$, and $174 \mathrm{Yb}$ was added (control of the chemical yield during the sample decomposition procedure), and moistened with several drops of deionized water. Then $0.5 \mathrm{ml}$ of $\mathrm{HClO}_{4}$ (Perchloric acid fuming 70\% Supratur, Merck), $3 \mathrm{ml}$ (HF Hydrofluoric acid 40\% GR, ISO, Merck), $0.5 \mathrm{ml}$ of HNO3 (Nitric acid 65\%, max. 0.0000005\%\% GR, ISO, Merck) and evaporated until intense white vapors appeared. The beakers were cooled, their walls were washed with water, and the solution was again evaporated to wet salts. Then $2 \mathrm{ml}$ of $\mathrm{HCl}$ (Hydrochloric acid fuming $37 \% \mathrm{OR}$, ISO, Merck) and $0.2 \mathrm{ml}$ of $0.1 \mathrm{M} \mathrm{H}_{3} \mathrm{BO}_{3}$ solution (analytical grade) were added and evaporated to a volume of $0.5-0.7 \mathrm{ml}$. The resulting solutions were transferred into polyethylene bottles, $0.1 \mathrm{ml}$ of a solution containing $10 \mathrm{mg} \mathrm{L}^{-1} \mathrm{In}$ (internal standard) was added, diluted with deionized water to $20 \mathrm{ml}$, and analysis was performed. As control samples in Teflon beakers, the above procedures were performed without samples, and the resulting solutions were used as controls. Along with the analyzed samples, the decomposition of standard samples was carried out. To check the correctness of the analysis of dust samples, we used multi-element standard samples Trapp ST-2a (Russian State Standard GSO 8671-2005) and Basalt BHVO-2 (US Geological Survey). The methods, recoveries and analytical results of certified reference materials are given in Supplementary Materials (Table 2).The detection limit (DL) for measured elements are listed in Table 2.

\section{Data analysis}

Statistical processing of the results was carried out using the Excel and Statistica 6.0 packages. Statistical indicators of the composition of road dust (mean, median, standard deviation) were determined for Tyumen as a whole and separately for roads with different traffic intensities. The significance of differences in mean values for roads with different traffic intensities was assessed using the Mann-Whitney test.

To assess the level of pollution, the following indices were calculated: contamination factor (Cf) geoaccumulation index (Igeo), enrichment factor (EF), integrated pollution index (IPI) and total pollution index Zc

The contamination factor is calculated based on the following equation:

$\mathrm{Cf}=\mathrm{Ci} / \mathrm{Cb}$

where $\mathrm{Ci}$ is the concentration of the particular element in the dust and $\mathrm{Cb}$ is the content of background values. For road dust, due to the absence of a background analogue, the content of elements was 
compared with the average content in the continental crust according to (Rudnisk, Gao, 2003).

Hakanson (1980) divided the contamination factor into four categories: $\mathrm{Cf}<1=$ low contamination factor indicating low contamination, $1 \leq \mathrm{Cf}<3=$ moderate contamination, $3 \leq \mathrm{Cf}<6=$ considerable contamination, $\mathrm{Cf} \geq 6$ = very high contamination.

Igeo index was calculated according to Müller (1969) using the following equation:

$$
\text { Igeo }=\log 2\left(\frac{C i}{1,5 C b}\right)
$$

where $\mathrm{Ci}$ is the measured concentration of the particular element and $\mathrm{Cb}$ is the geochemical background (crustal average). According to (Müller, 1969), the contamination level can be classified based on a scale, where Igeo $\leq 0$ classified as uncontaminated, $0<$ Igeo $\leq 1$ = slightly contaminated, $1<$ Igeo $\leq 2=$ moderately contaminated, $2<$ Igeo $\leq 3=$ moderately to heavily contaminated, $3<$ Igeo $\leq 4$ = heavily contaminated, $4<$ Igeo $\leq 5=$ heavily to extremely contaminated Igeo $>5=$ extremely contaminated (Müller 1969; Sutherland 2000).

The enrichment factor (EF) of an element, an important parameter for evaluating the impact degree of human activities on its enrichment, is the normalization of a measured element against a reference element in a studied sample (Al-Awadhi and AlShuaibi 2013). The EF was calculated according to equation:

$$
E F=\frac{c x}{A l}(\text { sample }) / \frac{c x}{A l}(\text { crust })
$$

$\mathrm{EF} \leq 2$ means deficiency to minimal enrichment, $2<\mathrm{EF} \leq 5$ corresponds to moderate enrichment, $5<\mathrm{EF} \leq 20$ signifies significant enrichment and significant pollution signal, $20<E F \leq 40$ indicates very high enrichment and very strong pollution signal and $40 \geq \mathrm{EF}$ means extremely high enrichment (Sutherland 2000; Yongming et al. 2006; Lu et al. 2009).

Further, based on the EF values, an assessment was made of the ratio between natural and anthropogenic sources that affect the composition of dust. A simple formula (Han et al. 2007; Chen et al. 2012) is used as below: assuming the concentration of element $X$ in resuspended road dust is the sum of the two sources: crustal and pollution, i.e.

$$
\begin{aligned}
& \mathrm{X} \text { road dust }=\mathrm{X} \text { crust }+\mathrm{X} \text { pollution } \\
& \mathrm{X} \text { crust }=\mathrm{Al} \text { road dust }(\mathrm{X} / \mathrm{Al}) \text { crust } \\
& \mathrm{X} \text { pollution } \%=(1-(\mathrm{Al} / \mathrm{X}) \text { road dust }(\mathrm{X} / \mathrm{Al}) \text { crust }) \times 100 \%
\end{aligned}
$$

The generalized level of road dust pollution by metals and metalloids was estimated using the total pollution indicator (Kasimov et al. 2012)

$$
Z c=\Sigma \mathrm{Cf}-(n-1)
$$


For $\mathrm{Cf}>1.5$, where $\mathrm{n}$ is the number of elements with $\mathrm{Cf}>1.5$

The following values are taken as gradations of the pollution level: $\mathrm{Zc}<32$ - non-hazardous pollution level, 32-64 - moderately hazardous, 64-128 - hazardous, 128-256 - very hazardous (Kasimov et al. 2012;

Vlasov et al. 2015).

Another method used for the determination of trace element contamination is the IPI, which is defined as the average of the contamination factors computed for each trace element (Tume et al. 2018). The IPI is divided into four categories: low pollution level $(I P \mid<1)$, moderate pollution level $(1<\mid \mathrm{PI}<2)$, high pollution level $(2<\mid \mathrm{PI}<5)$ and extremely high pollution index (IPI> 5) (Salmanighabeshi et al. 2015).

To make the results more easily interpretable and to determine sources of pollution, the PCA with VARIMAX normalized rotation was also applied. When PCA with VARIMAX normalized rotation was performed, each PC score contains information on all of the metal elements combined into a single number, while the loadings indicate the relative contribution each element makes to that score (Yongming et al. 2006)

\section{Results And Discussion}

\section{Physical and chemical properties of road dust}

Table 1 shows the physicochemical indicators and particle size distribution of road dust on roads with different traffic intensities.

Table 1. Physicochemical indicators of road dust in Tyumen on roads with different traffic intensities.

\begin{tabular}{|c|c|c|c|c|c|c|}
\hline \multirow[t]{3}{*}{ Parameter } & \multicolumn{6}{|c|}{ Traffic intensity } \\
\hline & \multicolumn{2}{|l|}{ Low } & \multicolumn{2}{|c|}{ Moderate } & \multicolumn{2}{|l|}{ High } \\
\hline & Mean & SD & Mean & SD & Mean & SD \\
\hline \multicolumn{7}{|c|}{ Granulometric composition } \\
\hline Sand (\%) & 86.6 & 5.1 & 76.8 & 11.7 & 81.3 & 7.4 \\
\hline Silt (\%) & 12.0 & 4.3 & 21.2 & 11.1 & 16.7 & 6.9 \\
\hline Clay (\%) & 1.5 & 0.8 & 2.1 & 0.7 & 2.0 & 0.6 \\
\hline Organic carbon (\%) & 0.68 & 0.35 & 1.22 & 0.57 & 1.01 & 0.44 \\
\hline $\mathrm{pH}$ & 8.10 & 0.42 & 7.82 & 0.34 & 8.06 & 0.51 \\
\hline
\end{tabular}

The dust has an alkaline reaction, the $\mathrm{pH}$ value varies from 7.4 to 10.2. The alkaline reaction is caused by the entry of microparticles of carbonate construction dust, as well as the redistribution of pollutants emitted by vehicles. Acidifying gaseous compounds, mainly nitrogen oxides, migrate off the roadway, while alkalizing dust particles (construction carbonate dust, deicing mixtures) remain on the road. The differences in the average $\mathrm{pH}$ values on roads with different traffic intensities are small (7.82 - 8.10) and, 
according to the Mann - Whitney test, are statistically insignificant. The content of organic matter varies from 0.07 to $2.9 \%$ (average $1.1 \%$ ). The minimum content of organic matter on roads with moderate traffic intensity, the maximum on roads with low traffic (Table 1).

Road dust from different cities of the world has a predominantly alkaline reaction of $\mathrm{pH} 7-10$, the content of $\mathrm{C}_{\text {org }}$ varies significantly - from 1 to 17\%, (Al-Khashman 2007; Ladonin and Plyaskina 2009; Acosta et al. 2011; Yisa et al. 2011; Hu et al. 2011; Sutherland et al. 2012; Vlasov et al. 2015; Gabarron et al. 2017). Thus, in terms of physical and chemical properties, the road dust of Tyumen does not differ from other cities on Earth.

The particle size distribution is dominated by the fine sand fraction (PM 100-250 $\mu \mathrm{m}$ ), the content of which is $52 \%$ on average (varying from 3.8 to $67.4 \%$ ). The content of very fine sand ( $P M=50-100 \mu \mathrm{m}$ ) is much less and averages $11.2 \%$. The content of the silt fraction is $18.1 \%(4.6-31.2 \%)$. The amount of clay particles $(P M<2 \mu \mathrm{m})$ is very low $(0.7-3.2 \%)$.

It is believed that the predominance of particles with a size of $180 \ldots 240 \mu \mathrm{m}$ in road dust is evidence of the influx of soil particles and particles associated with traffic - abrasion of the roadway, tires, metal parts of cars (Christoforidis and Stamatis 2009). Particles with a size of $60 \ldots 90 \mu \mathrm{m}$ come with emissions from industrial sources and thermal power plants thermal power plants (Krupnova et al. 2020). According to (Zaytseva et al. 2013), the dust particles less than $10 \mu \mathrm{m}$ is formed in all technological processes at metallurgical enterprises. A significant predominance of particles with a diameter of $100-250 \mu \mathrm{m}$ and a very small amount of PM $<10 \mu \mathrm{m}$ particles (Fig. 2) in the Tyumen road dust indicates a weak influence of industrial enterprises on its composition and the predominant effect of transport and soil erosion processes. Measurements of the number of particles PM 2.5 and PM 10 in the air confirm the low dustiness of the surface layer of the atmosphere in Tyumen. During the sampling period of road dust (June 2020), the average concentration of PM10 particles in the air was $0.020 \mathrm{mg} / \mathrm{m}^{3}$, which is significantly less than in most cities on Earth (Pozhitkov 2020).

Comparison of data on the granulometric composition of Tyumen road dust with data for other cities showed that the predominance of the sand fraction with a particle diameter of $P M>50$ is typical for road dust and weakly depends on the composition of urban soils, population size and industrial specialization. So, in Moscow, road dust has a predominantly sandy loam composition (sandy loam), the share of PM> 50 averages 69.1\%, PM10-50 - 16.3\%, PM1-10 - 12.8\%, PM <1 1, 8\% (Vlasov et al. 2015). In Chelyabinsk (Russia), road dust was dominated by particles ranging in size from $30 \ldots 40$ to $250 \ldots 300 \mu \mathrm{m}$, (Krupnova et al. 2020). In Turin (Italy), road dust was significantly dominated by fractions of 50-200 $\mu \mathrm{m}$ and 200$2000 \mu \mathrm{m}$, the content of which was 27 and 62\%, respectively (Padoan et al. 2017). In Shanghai, China, road dust is dominated by particles ranging in size from 100 to $400 \mu \mathrm{m}$ (Shi et al. 2011). The predominance of the sandy fraction in road dust is associated with the removal of $\mathrm{PM}<50 \mu \mathrm{m}$ particles, which rise during the movement of vehicles as a result of the action of turbulent eddies and can be carried even by weak winds (Vlasov et al. 2015). As the traffic intensity increases, the proportion of large sand particles in the composition of road dust increases (Nikiforova et al. 2011). 
The distribution of road dust fractions on roads with different traffic intensities in Tyumen is as follows (Fig. 2). The largest number of small particles (PM <2 and PM2-10), which are most easily carried by the wind and pose the greatest danger to public health, was noted on roads with medium traffic. Least of all small particles on roads with low traffic volume, large roads occupy an intermediate position. Differences in the particle size distribution of dust on small medium and large roads are small. Verification using the Mann-Whitney criterion showed that the difference in the average values of the content of particles of the same aerodynamic diameter, depending on the traffic intensity, was not significant. Probably, natural winds have a decisive influence, under the influence of which $\mathrm{PM}<50 \mu \mathrm{m}$ particles are carried away. The average wind speed in Tyumen is $3 \mathrm{~m} / \mathrm{s}$, during the sampling period (May) $-3.3 \mathrm{~m} / \mathrm{s}$ (Reference Book 1998). Even at low wind speeds $(2-3 \mathrm{~m} / \mathrm{s}$ ), particles $1-2 \mu \mathrm{m}$ in size do not settle due to gravity (Charron and Harrison 2005; Viana et al., 2006).

\section{Major elements}

The compositions of major elements in road dust of Tyumen are shown in Fig. 3. For comparison, the composition of Quaternary deposits (aeolian sand) in the vicinity of Tyumen is presented in accordance with (Sizov et al. 2020). The composition of road dust is dominated by $\mathrm{MgO}$ (on average $12.9 \%$ ), $\mathrm{CaO}$ (7.7\%) $\mathrm{Al}_{2} \mathrm{O}_{3}$ and $\mathrm{Fe}_{2} \mathrm{O}_{3}(5.2 \%)$. Then $\mathrm{K}_{2} \mathrm{O}, \mathrm{Na}_{2} \mathrm{O}, \mathrm{P}_{2} \mathrm{O}_{5}$ follow in descending order. In the continental crust (Rudnick and Gao 2003), the content of elements decreases in a slightly different sequence $\mathrm{MgO}$ (46.7\%), $\mathrm{Al}_{2} \mathrm{O}_{3}(15.4 \%), \mathrm{Fe}_{2} \mathrm{O}_{3}(5.0 \%), \mathrm{CaO}(3.6 \%) \mathrm{Na}_{2} \mathrm{O}(3.27 \%) \mathrm{K}_{2} \mathrm{O}$ (2.8\%). Thus, in comparison with the Earth's crust, road dust is enriched with calcium, which is caused by the intake of carbonate cement dust during abrasion of curbs, the use of anti-ice reagents. Road dust also contains significantly more $\mathrm{CaO}$ than sandy aeolian deposits. More $\mathrm{MgO}, \mathrm{P}_{2} \mathrm{O}_{5}, \mathrm{Fe}_{2} \mathrm{O}_{3}$ in road dust than in Quaternary sediments (see Fig. 3). The intake of phosphorus is associated with soil organic matter. $\mathrm{Fe}_{2} \mathrm{O}_{3}$ comes from the corrosion of metal parts of vehicles, magnesium is part of deicing agents.

\section{Trace elements content in road dust}

Table 2 shows statistics related to the contents of trace elements. A number of elements ( $\mathrm{Se}, \mathrm{Rh}, \mathrm{Pd}, \mathrm{Te}, \mathrm{Re}$, Ir, Pt, Au) were excluded from the calculations, since their content in more than $50 \%$ of the samples was below the detection limit. For other elements, in the event that the content was $<D L$, half the value of the $D L$ was indicated. Compared to the average content in the earth's crust, the Tyumen road dust is enriched in $\mathrm{Ni}$, $\mathrm{Sb}, \mathrm{Cr}, \mathrm{Zn}, \mathrm{Co}, \mathrm{Cu}, \mathrm{Pb}, \mathrm{Cd}, \mathrm{W}, \mathrm{Ag}$. The concentrations of $\mathrm{Mo}, \mathrm{As}, \mathrm{Sn}, \mathrm{Bi}$ are close to the average content in the earth's crust, the rest of the elements are in deficit. The concentrations of $\mathrm{Cu}\left(18-130.4 \mathrm{mg} \mathrm{kg}^{-1}\right), \mathrm{Ni}$ (322.4-1042 $\left.\mathrm{mg} \mathrm{kg}^{-1}\right), \mathrm{Hg}\left(0.01-0.15 \mathrm{mg} \mathrm{kg}^{-1}\right), \mathrm{Pb}\left(8.5-120.2 \mathrm{mg} \mathrm{kg}^{-1}\right)$, and $\mathrm{Cd}\left(0.02-0.44 \mathrm{mg} \mathrm{kg}^{-1}\right)$ in street dust of Tyumen varied greatly. This indirectly indicates the influence of pollution sources that cause an increase in the TMM content in road dust.

Table 2. Summary statistics of trace elements content in Tyumen road dust $(n=50)$. 


\begin{tabular}{|c|c|c|c|c|c|c|c|c|}
\hline Element & $\begin{array}{l}\text { Detection } \\
\text { limit }\end{array}$ & Mean & SD & Median & $\min$ & $\max$ & $\begin{array}{l}\text { Earth crust (Rudnik } \\
\text { and Gao 2003) }\end{array}$ & $\mathrm{Cf}$ \\
\hline Li & 0.03 & 6.8 & 1.4 & 6.7 & 4.1 & 10.2 & 21.0 & 0.32 \\
\hline $\mathrm{Be}$ & 0.03 & 0.6 & 0.14 & 0.6 & 0.4 & 1.0 & 2.1 & 0.29 \\
\hline Sc & 0.09 & 10.1 & 1.2 & 9.9 & 5.5 & 13.3 & 14.0 & 0.72 \\
\hline V & 0.8 & 66.4 & 10.5 & 66.5 & 27.5 & 104.9 & 97.0 & 0.68 \\
\hline $\mathrm{Cr}$ & 0.7 & 507.9 & 112.7 & 495.3 & 282.6 & 740.6 & 92.0 & 5.5 \\
\hline Co & 0.08 & 39.6 & 8.3 & 38.8 & 24.8 & 59.3 & 17.3 & 2.3 \\
\hline $\mathrm{Ni}$ & 0.7 & 632.1 & 164.7 & 617.2 & 322 & 1042 & 47.0 & 13.4 \\
\hline $\mathrm{Cu}$ & 0.8 & 57.4 & 21.5 & 52.2 & 18.0 & 130.4 & 28.0 & 2.1 \\
\hline $\mathrm{Zn}$ & 0.5 & 160.8 & 44.7 & 157.8 & 59.6 & 271 & 67.0 & 2.4 \\
\hline $\mathrm{Ga}$ & 0.1 & 5.2 & 0.8 & 5.3 & 3.1 & 6.6 & 17.5 & 0.29 \\
\hline As & 0.1 & 5.7 & 3.0 & 5.3 & 1.7 & 20.9 & 4.8 & 1.19 \\
\hline $\mathrm{Rb}$ & 0.1 & 27.1 & 6.4 & 28.0 & 15.6 & 40.3 & 84.0 & 0.32 \\
\hline $\mathrm{Sr}$ & 0.07 & 147.3 & 28.9 & 145.8 & 100 & 244 & 320 & 0.46 \\
\hline Y & 0.02 & 7.3 & 1.6 & 7.5 & 3.1 & 10.7 & 21.0 & 0.35 \\
\hline $\mathrm{Zr}$ & 0.04 & 60.7 & 21.2 & 60.4 & 17.4 & 133.5 & 193.0 & 0.31 \\
\hline $\mathrm{Nb}$ & 0.02 & 6.6 & 2.4 & 6.3 & 1.7 & 12.4 & 12.0 & 0.55 \\
\hline Mo & 0.04 & 1.4 & 0.7 & 1.2 & 0.53 & 4.6 & 1.1 & 1.30 \\
\hline $\mathrm{Ag}$ & 0.03 & 0.076 & 0.038 & 0.07 & 0.04 & 0.31 & 0.053 & 1.4 \\
\hline $\mathrm{Cd}$ & 0.04 & 0.2 & 0.08 & 0.15 & 0.02 & 0.44 & 0.09 & 1.8 \\
\hline Sn & 0.03 & 2.2 & 1.0 & 1.9 & 0.6 & 5.8 & 2.1 & 1.05 \\
\hline $\mathrm{Sb}$ & 0.06 & 3.1 & 1.9 & 2.6 & 1.1 & 13.2 & 0.4 & 7.8 \\
\hline Cs & 0.01 & 0.9 & 0.20 & 0.84 & 0.4 & 1.4 & 4.90 & 0.17 \\
\hline $\mathrm{Ba}$ & 0.05 & 317.1 & 69.7 & 328.4 & 177.6 & 435.8 & 624 & 0.51 \\
\hline La & 0.009 & 8.9 & 2.7 & 8.9 & 3.7 & 15.2 & 31.0 & 0.29 \\
\hline $\mathrm{Ce}$ & 0.008 & 20.1 & 5.6 & 20.3 & 8.4 & 31.2 & 63.0 & 0.32 \\
\hline $\mathrm{Pr}$ & 0.005 & 2.0 & 0.6 & 2.1 & 0.9 & 3.3 & 7.1 & 0.29 \\
\hline $\mathrm{Nd}$ & 0.009 & 8.7 & 2.5 & 9.0 & 4.2 & 14.8 & 27.0 & 0.32 \\
\hline Sm & 0.004 & 1.6 & 0.4 & 1.6 & 0.8 & 2.8 & 4.7 & 0.35 \\
\hline
\end{tabular}




\begin{tabular}{|lllllllll|}
\hline $\mathrm{Eu}$ & 0.006 & 0.4 & 0.09 & 0.42 & 0.22 & 0.62 & 1.0 & 0.43 \\
\hline $\mathrm{Gd}$ & 0.007 & 1.4 & 0.34 & 1.5 & 0.63 & 2.2 & 4.0 & 0.36 \\
\hline $\mathrm{Tb}$ & 0.004 & 0.2 & 0.05 & 0.22 & 0.10 & 0.33 & 0.7 & 0.31 \\
\hline $\mathrm{Ho}$ & 0.007 & 1.3 & 0.30 & 1.32 & 0.55 & 2.0 & 3.9 & 0.34 \\
\hline $\mathrm{Er}$ & 0.003 & 0.8 & 0.17 & 0.82 & 0.36 & 1.19 & 2.3 & 0.33 \\
\hline $\mathrm{Tm}$ & 0.004 & 0.1 & 0.03 & 0.12 & 0.04 & 0.17 & 0.3 & 0.35 \\
\hline $\mathrm{Yb}$ & 0.003 & 0.8 & 0.2 & 0.8 & 0.29 & 1.3 & 2.0 & 0.39 \\
\hline $\mathrm{Lu}$ & 0.005 & 0.1 & 0.0 & 0.1 & 0.04 & 0.20 & 0.3 & 0.41 \\
\hline $\mathrm{Hf}$ & 0.02 & 1.9 & 0.7 & 1.8 & 0.5 & 4.8 & 5.3 & 0.40 \\
\hline $\mathrm{Ta}$ & 0.01 & 0.5 & 0.24 & 0.5 & 0.15 & 1.8 & 0.9 & 0.35 \\
\hline $\mathrm{W}$ & 0.03 & 3.2 & 1.3 & 3.1 & 0.8 & 7.1 & 1.9 & 0.61 \\
\hline $\mathrm{Hg}$ & 0.01 & 0.024 & 0.021 & 0.019 & 0.005 & 0.146 & 0.1 & 0.48 \\
\hline $\mathrm{Tl}$ & 0.005 & 0.143 & 0.026 & 0.146 & 0.1 & 0.2 & 0.9 & 0.16 \\
\hline $\mathrm{Pb}$ & 0.06 & 33.9 & 20.7 & 28.7 & 8.5 & 120.2 & 17.0 & 2.0 \\
\hline $\mathrm{Bi}$ & 0.01 & 0.17 & 0.28 & 0.12 & 0.03 & 2.08 & 0.2 & 1.07 \\
\hline $\mathrm{Th}$ & 0.01 & 1.9 & 0.6 & 1.9 & 0.7 & 3.5 & 10.5 & 0.18 \\
\hline $\mathrm{U}$ & 0.01 & 1.1 & 0.5 & 1.0 & 0.50 & 4.4 & 2.7 & 0.41 \\
\hline
\end{tabular}

The values of the pollution index $\mathrm{Cf}$ are maximal for $\mathrm{Ni}, \mathrm{Sb}, \mathrm{Cr}, \mathrm{Zn}$, Co (Table 2). According to the classification of Hakanson (1980), in terms of Cf, the content of Co, Cu, Zn, As, Mo, Ag, Cd, Sn, W, Pb Bi corresponds to the level of "moderate contamination", $\mathrm{Cr}$ - "significant contamination" and $\mathrm{Ni}, \mathrm{Sb}$ - "very high contamination". The pollution of road dust in Tyumen with chromium and nickel was previously noted by Konstantinova et al. (2020), who revealed that the concentration of these elements is 4 and 7 times higher, respectively, compared to urban soils. An increased content of $\mathrm{Cr}, \mathrm{Ni}, \mathrm{Pb}, \mathrm{V}$ was also noted in the snow cover (Guseinov et al. 1997), which confirms the atmospheric input of these metals.

\section{Geoaccumulation index and enrichment factor}

The calculated results of Igeo of heavy metals in road dust from Tyumen are presented in Fig. 4. In terms of Igeo values, the elements form the following row: $\mathrm{Ni}_{2.2} \mathrm{Sb}_{1.5} \mathrm{Cr}_{1.3} \mathrm{Zn}_{0.4} \mathrm{Co}_{0.4} \mathrm{Cu}_{0.2} \mathrm{Cd}_{0.1} \mathrm{~Pb}{ }_{0.1} \mathrm{~W}_{0.04}$ (the index denotes the average of the Igeo). For the rest of the elements, Igeo $<0$. Thus, according to the classification (Müller 1969), Ni belongs to the category "moderately to heavily contaminated", $\mathrm{Sb}, \mathrm{Cr}$ "moderately contaminated", Zn, Co, Cu, Cd, Pb, W - "slightly contaminated". As Cd, Ag, Mo, Sn, $\mathrm{Hg}, \mathrm{Sb}, \mathrm{Pb}$ are characterized by a wide variation in Igeo values (Fig. 3), depending on local sources of pollution. For 
example, for $\mathrm{Pb}$, the values of Igeo> 1, corresponding to the "moderately contaminated" level, were noted near the car battery production plant. Earlier it was revealed that the concentration of $\mathrm{Pb}$ in the soils on the territory of the battery plant is extremely high (>1000 mg kg-1) (Skipin and Beresneva, 2014).

The value of EF values on roads with different traffic intensities is given in Table 3 (only metals with EF values> 1.5 are presented). On roads with low traffic volumes, the $\mathrm{EF}$ value of $\mathrm{Ni}, \mathrm{Co}, \mathrm{Cr}, \mathrm{Sb}$ is lower than on roads with high and medium traffic volumes. Verification using the Mann-Whitney test showed that small roads significantly differ from medium and large ones in the enrichment of road dust with chromium, nickel, antimony, mercury and bismuth $(p=0.01)$. Differences between the EF of cadmium for small and large roads are also significant. Differences in the content of other elements are statistically insignificant. Thus, the EF calculations confirm the effect of transport on the release of $\mathrm{Ni}, \mathrm{Cr}$, Sb into the environment. An assessment of the ratio between natural and anthropogenic sources affecting the composition of dust, carried out in accordance with formulas 4-6, showed that the elements form the following series (the index means the share of anthropogenic input, \%): $\mathrm{Ni}_{97} \mathrm{Sb}_{95} \mathrm{Cr}_{93} \mathrm{Zn}_{85} \mathrm{Co}_{84} \mathrm{Cu}_{82} \mathrm{~Pb}_{79} \mathrm{~W}_{76} \mathrm{Cd}_{76} \mathrm{Ag}_{74} \mathrm{Mo}_{71}$ $\mathrm{Sn}_{61} \mathrm{Sc}_{53} \mathrm{Bi}_{52} \mathrm{~V}_{50}$. The rest of the elements come primarily from natural sources.

Table 3. EF values on roads with different traffic volumes. 


\begin{tabular}{llll} 
Elements & \multicolumn{3}{l}{ Traffic intensity } \\
\cline { 2 - 4 } & low & moderate & high \\
\hline $\mathrm{Ni}$ & 23.7 & 33.6 & 33.7 \\
\hline $\mathrm{Sb}$ & 16.7 & 21.9 & 19.8 \\
\hline $\mathrm{Cr}$ & 10.3 & 13.9 & 13.6 \\
\hline $\mathrm{Pb}$ & 5.6 & 5.6 & 3.9 \\
\hline $\mathrm{Cd}$ & 5.5 & 5.0 & 3.6 \\
\hline $\mathrm{Zn}$ & 4.9 & 6.1 & 5.7 \\
\hline $\mathrm{Cu}$ & 4.7 & 5.2 & 4.7 \\
\hline $\mathrm{Co}$ & 4.4 & 5.7 & 5.7 \\
\hline $\mathrm{Mo}$ & 3.3 & 3.3 & 2.9 \\
\hline $\mathrm{W}$ & 3.5 & 4.2 & 4.2 \\
\hline $\mathrm{As}$ & 3.1 & 2.8 & 2.9 \\
\hline $\mathrm{Ag}$ & 3.2 & 3.8 & 3.2 \\
\hline $\mathrm{Sn}$ & 2.0 & 2.7 & 2.5 \\
\hline $\mathrm{Bi}$ & 1.6 & 2.2 & 3.2 \\
\hline $\mathrm{Hg}$ & 1.9 & 1.2 & 1.0 \\
\hline $\mathrm{Sc}$ & 1.69 & 1.75 & 1.73 \\
\hline $\mathrm{V}$ & 1.74 & 1.66 & 1.60 \\
\hline
\end{tabular}

It is characteristic that on small roads the dust is enriched with some chalcophilic elements $(\mathrm{Hg}, \mathrm{As}, \mathrm{Pb}$, $\mathrm{Cd}$ ). This is probably due to the influence of burning coal for heating private residential buildings, which prevail in urban areas with low traffic. Combustion of hard coal is the major source of airborne $\mathrm{Hg}, \mathrm{Mo}$ and a very significant source for As, Cr, Mn, Sb (Nriagu and Pacyna 1988).

To assess the features of pollution in Tyumen, we compared the calculated EF values with the EF values in other cities of the Earth (Table 4). In Tyumen, the composition of elements enriched in road dust differs sharply from other cities. As a rule, in most cities on Earth, the maximum degree of enrichment is characteristic of chalcophilic elements, which are highly mobile. In Changsha City, the mean EFs revealed the following order: $\mathrm{Cd}>\mathrm{Zn} \approx \mathrm{Pb} \approx \mathrm{Cu}>\mathrm{Cr}$ (Li et al. 2016). Similarly, in Kabul (Afghanistan), the EF values decrease in the sequence $\mathrm{Cd}>\mathrm{Pb}>\mathrm{Zn}>\mathrm{Cu}>\mathrm{Ni}>\mathrm{Cr}$ (Jadoon 2018). In Beijing, bulk atmospheric deposition $\mathrm{Cd}$ is the most anthropogenic enrichment metal with an EF of 32.4 proceeding As (11.5), $\mathrm{Zn}$ (9.3), $\mathrm{Pb}$ (7.7), and $\mathrm{Cu}$ (5.4) (Guo et al. 2017). In Tyumen, a different distribution of EF values is observed, which decrease 
in the sequence $\mathrm{Ni}>\mathrm{Cr}>\mathrm{Zn} \mathrm{Co}>\mathrm{Pb}>\mathrm{Cd}$. To understand the reasons for the identified differences, it is necessary to determine the sources of the main road dust pollutants in Tyumen.

Table 4 The average EFs values of heavy metals in road dust collected in different areas

\begin{tabular}{|c|c|c|c|c|c|c|c|c|c|c|}
\hline City, country & $\mathrm{Cr}$ & Co & $\mathrm{Ni}$ & $\mathrm{Cu}$ & $\mathrm{Zn}$ & As & $\mathrm{Cd}$ & $\mathrm{Pb}$ & $\mathrm{Mn}$ & Reference \\
\hline $\begin{array}{l}\text { Tyumen, this } \\
\text { study }\end{array}$ & 13,3 & 5,5 & 32,3 & 4,9 & 5,8 & 2,9 & 4,4 & 4,8 & 2,8 & $\begin{array}{l}\text { This } \\
\text { study }\end{array}$ \\
\hline $\begin{array}{l}\text { Kabul, } \\
\text { Afghanistan }\end{array}$ & 1.10 & 0.82 & 1.76 & 2.46 & 3.92 & - & 8.75 & 5.97 & 0.88 & $\begin{array}{l}\text { Jadoon } \\
2018\end{array}$ \\
\hline $\begin{array}{l}\text { Bayan Obo, } \\
\text { China }\end{array}$ & 5.31 & 3.98 & 2.53 & 3.74 & 8.82 & 2.7 & $\underline{81.4}$ & 19.5 & 11.0 & $\begin{array}{l}\text { Li et al. } \\
2015\end{array}$ \\
\hline $\begin{array}{l}\text { Changsha } \\
\text { City,China }\end{array}$ & 1.71 & - & - & 2.6 & 4.0 & - & 128.0 & 3.41 & - & $\begin{array}{l}\text { Li et al. } \\
2016\end{array}$ \\
\hline $\begin{array}{l}\text { Tongchin, } \\
\text { China }\end{array}$ & 1.74 & 3.32 & 0.88 & 1.55 & 2.04 & 0.61 & - & 3.58 & 0.67 & $\begin{array}{l}\text { Zhang et } \\
\text { al. } 2015\end{array}$ \\
\hline Dehli, India & $\begin{array}{l}3.5- \\
16.1\end{array}$ & - & $2-3$ & $\begin{array}{l}3.3- \\
22.4\end{array}$ & $\begin{array}{l}3.3- \\
7.3\end{array}$ & - & - & $\begin{array}{l}5.1- \\
21.9\end{array}$ & - & $\begin{array}{l}\text { Rajaram } \\
\text { et al. } \\
2014\end{array}$ \\
\hline
\end{tabular}

$\mathrm{EF} \leq 2$ means deficiency to minimal enrichment; normal font - $2<\mathrm{EF} \leq 5$ - moderate enrichment; bold italic $5<\mathrm{EF} \leq 20$ means significant enrichment; bold - $20<\mathrm{EF} \leq 40$ - very high enrichment; bold with underline $40 \geq E F$ - extremely high enrichment

\section{Identification of sources of pollution.}

Studies have shown that $\mathrm{Ni}, \mathrm{Sb}, \mathrm{Cr}, \mathrm{Zn}, \mathrm{Co}$ are the main road dust pollutants in Tyumen. The content of these elements is increased throughout the city. $\mathrm{Ni}, \mathrm{Cr}$, Co belong to the geochemical group of siderophilic elements (Kabata-Pendias 2011) i.e. elements related to iron.The main source of nickel and chromium pollution is metallurgical plants (Saet et al 1990). Elements related to ironworking activities are $\mathrm{Fe}, \mathrm{Co}, \mathrm{Cr}$, Mn, Ni (Zibert and Rokavec 2010). In Tyumen, the few and low-power metallurgical and metal-working enterprises (Tyumen electrometallurgical plant, JSC Sibneftemash, Zavod Tyumenremdormash CJSC) do not cause road dust pollution throughout the city, since no increase in $\mathrm{Ni}$ and $\mathrm{Cr}$ was found in their locations. Only the influence of the Tyumen Battery Plant, in the area of which a high lead content was found, has been reliably confirmed.

Soils are a natural source of $\mathrm{Ni}$ input. In the soils of Tyumen, the Ni content is increased, its average concentration is, according to various estimates, from $46.5 \mathrm{mg} \mathrm{kg}^{-1}$ (Konstantinova et al. 2019) to $95 \mathrm{mg}$ $\mathrm{kg}^{-1}$ (Moskovchenko 1998), which is significantly higher than the average world content in the surface horizon of background chernozem soils constituting, according to (Kabata-Pendias 2011) $25 \mathrm{mg} \mathrm{kg}^{-1}$. However, the $\mathrm{Ni}$ content in road dust is one mathematical order of magnitude higher than in soil (on average $632 \mathrm{mg} \mathrm{kg}^{-1}$, see Table 2). Similarly, the average $\mathrm{Cr}$ content in the soils of Tyumen is estimated 
from $107 \mathrm{mg} \mathrm{kg}^{-1}$ (Konstantinova et al. 2019) to $176 \mathrm{mg} \mathrm{kg}^{-1}$ (Moskovchenko 1998), with an average world value for chernozems of $77 \mathrm{mg} \mathrm{kg}^{-1}$ (Kabata-Pendias, 2011). But in Tyumen road dust, the concentration of Cr exceeds $500 \mathrm{mg} \mathrm{kg}^{-1}$. Co content in soils $16-20.9 \mathrm{mg} \mathrm{kg}^{-1}$ (Moskovchenko 1998; Konstantinova et al. 2019), in road dust $39.6 \mathrm{mg} \mathrm{kg}^{-1}$. A significant excess of the content of $\mathrm{Ni}, \mathrm{Cr}$, Co in road dust compared to soils, as well as an increased content in snow of Tyumen (Guseinov et al. 1997), gives grounds for the conclusion that there are anthropogenic sources of these elements.

According to Yang et al. (2010), Ni, Fe, Cr enter city dust mainly from transport. At the same time, the sources of $\mathrm{Ni}$ input are diverse. The most important source of $\mathrm{Ni}$ is the combustion of petroleum and petroleum products (Nriagu and Pacyna 1988). Global emission of Ni from oil products combustion it is estimated to range from 10 to $>40 \mathrm{kt} \mathrm{yr}^{-1}$ (Kabata-Pendias 2011). Diesel engines use fuels with Ni additives (Al-Khashman 2007). Nickel in road dust is also found in asphalt bitumen and gabbro rock material (Lindgren (1996). Crushed stone used in road construction in Tyumen consists of rocks, including gabbro. Corrosion of metal parts of motor vehicles is a significant source of Ni (Ferguson and Kim 1991; Akhter and Al-Jowder 1997; Atiemo et al. 2011) Cr, Co and W also come with metal abrasive dusts, including as a result of abrasion of metal part s of vehicles (Saet et al 1990).

In addition road dust pollutants in Tyumen are $\mathrm{Sb}, \mathrm{Zn}, \mathrm{Cu}, \mathrm{Cd}, \mathrm{Pb}, \mathrm{W}$. Antimony used in the manufacture of car batteries. Abrasion of tires, metal parts of cars and road markings is also a source of Sb (Vlasov et al. 2015; Ozaki et al.2021). As noted by Hjortenkrans et al. (2006) on motorway sections where traffic is braked (traffic lights, intersections, etc.) in decelerating environments such as roads with traffic lights, roundabouts and intersections, the $\mathrm{Sb}$ concentration was more than 8 times the background level. Similarly, Amato et al. (2009), studying the variability of the chemical composition of road dust in Spain, found that Sb, Zn and Mo are concentrated in the areas of vehicle braking, showing a strong relationship with brake pad and tire wear. It was also noted that $\mathrm{Sb}, \mathrm{As}, \mathrm{Sn}$ are supplied by burning coal for heating residential buildings (Landing et al., 2010).

Zinc and copper are also classified as elements which largely come to the environment from transport. Zn may have its origin from automotive sources, such as wear and tear of vulcanized rubber tires, lubricating oils, and corrosion of galvanized vehicular parts (Banerjee 2003; Ellis and Revitt 1982). Zn is added to tire tread as zinc oxide and organozinc compounds to facilitate the vulcanization process (Dall'Osto et al. 2014). The concentration of $\mathrm{Zn}$ in car tires is about 1\% (Adachi and Tainosho 2004), Principal source of $\mathrm{Cu}$ in the atmosphere is mainly fossil fuel burning, traffic emissions, fuel combustion, and industrial combustion (Nriagu 1996).

To clarify the sources of pollution, a PCA analysis of the obtained data set was carried out, including the content of macro- and microelements, physical and chemical properties and particle size distribution. PCA with VARIMAX normalized rotation was applied to assist in the identification of sources of pollutants. The essence of PCA analysis is to "fold" a multicomponent data set to a limited, user-selected number of factors that determine the sample variance. The results obtained made it possible to identify 3 main components (PC), which determine the regularities of the formation of the chemical composition of road dust (Table 5). 
Table 5. Varimax rotated principal component (PC) loadings for element concentrations, $\mathrm{pH}$ and clay content in road dust samples. 


\begin{tabular}{|c|c|c|c|}
\hline Variables & PC1 & PC 2 & PC 3 \\
\hline V & -0.04 & 0.13 & 0.69 \\
\hline $\mathrm{Cr}$ & 0.92 & 0.11 & -0.21 \\
\hline Co & 0.93 & 0.16 & -0.16 \\
\hline $\mathrm{Ni}$ & 0.92 & 0.10 & -0.26 \\
\hline $\mathrm{Cu}$ & -0.14 & 0.26 & 0.61 \\
\hline $\mathrm{Zn}$ & 0.15 & 0.77 & 0.08 \\
\hline As & 0.32 & 0.41 & -0.15 \\
\hline Mo & -0.14 & 0.52 & 0.33 \\
\hline $\mathrm{Ag}$ & -0.25 & 0.32 & 0.03 \\
\hline $\mathrm{Cd}$ & 0.04 & 0.69 & 0.13 \\
\hline Sn & 0.22 & 0.62 & 0.09 \\
\hline $\mathrm{Sb}$ & -0.04 & 0.54 & 0.14 \\
\hline W & 0.47 & 0.60 & 0.07 \\
\hline $\mathrm{Hg}$ & -0.35 & 0.24 & -0.03 \\
\hline $\mathrm{Pb}$ & -0.24 & 0.51 & 0.10 \\
\hline $\mathrm{Bi}$ & 0.17 & 0.32 & -0.18 \\
\hline $\mathrm{MgO}$ & 0.88 & 0.21 & -0.37 \\
\hline $\mathrm{Al}_{2} \mathrm{O}_{3}$ & -0.65 & 0.24 & 0.58 \\
\hline $\mathrm{P}_{2} \mathrm{O}_{5}$ & -0.01 & 0.65 & -0.13 \\
\hline$S$ & 0.42 & 0.54 & 0.02 \\
\hline $\mathrm{K}_{2} \mathrm{O}$ & -0.80 & -0.07 & 0.45 \\
\hline $\mathrm{CaO}$ & 0.34 & 0.41 & 0.02 \\
\hline $\mathrm{TiO}_{2}$ & -0.48 & -0.09 & 0.68 \\
\hline $\mathrm{MnO}$ & 0.05 & 0.33 & 0.83 \\
\hline $\mathrm{Fe}_{2} \mathrm{O}_{3}$ & 0.75 & 0.17 & 0.51 \\
\hline$C_{\text {total. }}$ & 0.12 & 0.53 & -0.70 \\
\hline Clay & 0.12 & 0.53 & -0.70 \\
\hline $\mathrm{pH}$ & -0.17 & 0.03 & 0.49 \\
\hline
\end{tabular}

Page 16/31 


\begin{tabular}{|llll|}
\hline Expl.Var & 6.25 & 4.90 & 4.50 \\
\hline Variance, \% & 22 & 17 & 16 \\
\hline
\end{tabular}

Factor loads are classified as "strong", "medium" and "weak" with values> 0.75; 0.75-0.50 and 0.5-0.3, respectively (Liu et al. 2003). Heavy loads are shown in bold in Table 5. The three PCs together account for $55 \%$ of the variance. The first component explains $22 \%$ of the total variance and has strong loading of $\mathrm{Cr}$, $\mathrm{Co}, \mathrm{Ni}, \mathrm{MgO}, \mathrm{Fe}_{2} \mathrm{O}_{3}$. This $\mathrm{PC}$ is to be associated with the traffic sources. The second factor has strong loading of $\mathrm{Zn}$ and moderate loading of $\mathrm{Mo}, \mathrm{Cd}, \mathrm{Sn}, \mathrm{Sb}, \mathrm{W}, \mathrm{P}, \mathrm{P}_{2} \mathrm{O}_{5}, \mathrm{~S}, \mathrm{C}_{\text {total }}$, clay content. The most important source of $\mathrm{Cd}$ and $\mathrm{Zn}$ is the combustion of solid fuels and household waste (Saet et al 1990; Nriagu and Pacyna 1988), which gives grounds to associate this PC with the influence of household activities of the population. The third factor account for $16 \%$ of the total variance. It is composed of $\mathrm{MnO}$ (strong correlated), $\mathrm{V}, \mathrm{TiO}_{2}, \mathrm{Cu}, \mathrm{Al}_{2} \mathrm{O}_{3}, \mathrm{C}_{\text {total. }}$ and clay content (moderate correlated). This factor can be interpreted as a natural factor of soil erosion. A similar distribution of factor loads was established in the soils of Tyumen. According to Konstantinova et al. (2020) V - Cr - Co - Ni - Cu association had the most significant strong positive value ( $47.5 \%$ of total variance).

\section{Environmental assessment}

The value of the total pollution index IPI, which takes into account the contents of all elements, varies in a small range, from 0.66 to 1.95 . Low pollution level $(\mathrm{IPI}<1)$ is noted at 2 points. All others belong to the moderate pollution level $(1<\mid \mathrm{PI}<2)$. Calculations of the total pollution index $\mathrm{Zc}$, which takes into account only those elements whose content is 1.5 higher than the background level and excludes random variations, showed that in $82 \%$ of cases the pollution level is moderate $(Z c=32-64)$. A hazardous level of pollution was detected at 1 sampling point, low, non-hazardous - in 16\%. The maximum value of Zc was noted at the sampling point located in the industrial zone of the city, near the thermal power plant. At this observation point, an abnormal concentration of antimony $\left(13.2 \mathrm{mg} \mathrm{kg}^{-1}\right)$ and zinc $\left(258 \mathrm{mg} \mathrm{kg}^{-1}\right)$ was detected. Thus, various indices showed that the level of road dust pollution in Tyumen is generally moderate.

To assess the ecological situation in Tyumen, we made a comparison with the data obtained in various cities of the Earth (Table 6). The concentration of trace elements in the road dust of different cities is very different, which is caused by differences in the intensity of the traffic load, the use of fuel of different composition, the characteristics of the road surface, the soils prevailing in the city, etc. The comparison shows that Tyumen has significant pollution with nickel, cobalt and chromium. Both our data and the data obtained earlier by Konstantinova et al. (2020) indicate that Tyumen is far superior to other cities in the concentration of these elements. The average concentration of $\mathrm{Ni}$ and $\mathrm{Cr}$ in the road dust of Tyumen is one order of magnitude higher than in other cities of Russia and the Earth as a whole. The content of $\mathrm{Cu}, \mathrm{Zn}, \mathrm{As}$, $\mathrm{Sb}$ relative to other cities is at an average level, and $\mathrm{Pb}, \mathrm{Cd}$ is rather low.

Table 6. Literature data on published metal median concentrations $\left(\mathrm{mg} \mathrm{kg}^{-1}\right)$ in street dust from cities around the world. 


\begin{tabular}{|c|c|c|c|c|c|c|c|c|c|c|}
\hline City, country & $\mathrm{Cr}$ & Co & $\mathrm{Ni}$ & $\mathrm{Cu}$ & $\mathrm{Zn}$ & As & $\mathrm{Cd}$ & $\mathrm{Pb}$ & $\mathrm{Sb}$ & Reference \\
\hline $\begin{array}{l}\text { Tyumen, } \\
\text { this study }\end{array}$ & 508 & 39,6 & 632 & 57,4 & 161 & 5,7 & 0,2 & 33,9 & 3,1 & This study \\
\hline $\begin{array}{l}\text { Tyumen, } \\
\text { Russia }\end{array}$ & 415,4 & 25,6 & 324 & 51,3 & 105 & 8,8 & 0,19 & 20,1 & 1,83 & $\begin{array}{l}\text { Konstantinova } \\
\text { et al. } 2020\end{array}$ \\
\hline $\begin{array}{l}\text { Moscow, } \\
\text { Russia }\end{array}$ & 50 & 8,0 & 26 & 93 & 252 & 2,8 & 0,61 & 53 & 4,6 & $\begin{array}{l}\text { Vlasov et al. } \\
2015\end{array}$ \\
\hline $\begin{array}{l}\text { Chelyabinsk, } \\
\text { Russia }\end{array}$ & 48,5 & 6,3 & 21,9 & 55,9 & 154 & 3,8 & 0,4 & 14,4 & 1,3 & $\begin{array}{l}\text { Krupnova et } \\
\text { al. } 2020\end{array}$ \\
\hline $\begin{array}{l}\text { Alushta, } \\
\text { Crimea }\end{array}$ & 31 & 7.4 & 33 & 44 & 127 & 8.0 & 0.3 & 37 & 1,5 & $\begin{array}{l}\text { Kasimov et al. } \\
2019 a\end{array}$ \\
\hline $\begin{array}{l}\text { Ottawa, } \\
\text { Canada }\end{array}$ & 43.3 & 8.3 & 15.2 & 65.8 & 112 & 1.3 & 0.6 & 39 & 0.89 & $\begin{array}{l}\text { Rasmussen et } \\
\text { al. } 2001\end{array}$ \\
\hline $\begin{array}{l}\text { Kabul, } \\
\text { Afganistan }\end{array}$ & 38.4 & 8.52 & 66.4 & 43.6 & 122.5 & - & 1.16 & 28.7 & - & Jadoon 2018 \\
\hline $\begin{array}{l}\text { Hangzhou, } \\
\text { China }\end{array}$ & 51 & 20 & 26 & 116 & 321 & - & 1.59 & 202 & - & $\begin{array}{l}\text { Zhang and } \\
\text { Wang (2009) }\end{array}$ \\
\hline $\begin{array}{l}\text { Guangzhou, } \\
\text { China }\end{array}$ & $\begin{array}{l}36- \\
176\end{array}$ & $\begin{array}{l}2.8- \\
8.8\end{array}$ & $\begin{array}{l}9.4- \\
48.3\end{array}$ & $\begin{array}{l}\text { 69- } \\
376\end{array}$ & $\begin{array}{l}196- \\
1150\end{array}$ & - & & $\begin{array}{l}40.5- \\
406\end{array}$ & - & Bi et al. 2013 \\
\hline $\begin{array}{l}\text { Urumqi, } \\
\text { China }\end{array}$ & 54.3 & 10.9 & 43.3 & 94.5 & 294 & - & 1.17 & 53.5 & - & $\begin{array}{l}\text { Wei et al. } \\
2010\end{array}$ \\
\hline $\begin{array}{l}\text { Tongchuan, } \\
\text { China }\end{array}$ & 106.5 & 31.7 & 25.3 & 32.4 & 142 & 6.7 & - & 75.2 & - & $\begin{array}{l}\text { Zhang et } \\
\text { al. } 2015\end{array}$ \\
\hline Seul, Korea & 151 & - & - & 396 & 795 & - & - & 144 & & $\begin{array}{l}\text { Kim et al. } \\
2007\end{array}$ \\
\hline $\begin{array}{l}\text { Dhanbad } \\
\text { and Bokaro } \\
\text { region, India }\end{array}$ & 57 & 10 & 24 & 26 & 78 & - & - & 48 & - & Singh 2011 \\
\hline $\begin{array}{l}\text { Luanda, } \\
\text { Angola }\end{array}$ & 26 & 2.9 & 10 & 42 & 317 & 5.0 & 1.1 & 351 & 3.4 & $\begin{array}{l}\text { Ferreira- } \\
\text { Baptista and } \\
\text { De Miguel } \\
2005\end{array}$ \\
\hline $\begin{array}{l}\text { Oslo, } \\
\text { Norway }\end{array}$ & - & 19 & 41 & 123 & 412 & - & 1.4 & 180 & 6.0 & $\begin{array}{l}\text { De Miguel et } \\
\text { al.1997 }\end{array}$ \\
\hline Xi'an, China & 145 & 30.9 & 30,8 & 54.7 & 268.6 & - & - & 124.5 & - & $\begin{array}{l}\text { Pan et al., } \\
2017\end{array}$ \\
\hline $\begin{array}{l}\text { Manchester, } \\
\text { UK }\end{array}$ & - & - & - & 113 & 282 & - & - & 653 & - & $\begin{array}{l}\text { Robertson et } \\
\text { al. } 2003\end{array}$ \\
\hline
\end{tabular}

The high level of $\mathrm{Ni} \mathrm{Cr}$ Co content in the Tyumen road dust is caused, in our opinion, by several reasons. Firstly, the increased content of these elements in soils, caused by natural lithological features, affects. The 
enrichment of soils and parent rocks of $\mathrm{Cr}$ and $\mathrm{Ni}$ in the vicinity of Tyumen was noted by Konstantinova et al. (2019). Secondly, there is a large number of cars in the city and a high traffic load, which leads to a significant intake of these microelements due to corrosion and abrasion of metal parts. In our opinion, the abrasion of the studs used in the "winter" anti-icing tires contributes to the pollution. The body of the studs is made of either aluminum alloy or steel, the core is made of tungsten carbide. In the cheaper tires, which are widely used in Tyumen, the studs have a steel shell. Considering that, winter tires in Tyumen are used for almost half a year, the abrasion of steel studs is a significant source of $\mathrm{Fe}, \mathrm{Ni}, \mathrm{Cr}$, Co - those elements, the content of which is increased in Tyumen compared to other cities.

\section{Conclusion}

In the presented work, the composition of road dust in Tyumen, an intensively developing industrial city in Siberia, has been studied. The physicochemical parameters, particle size distribution, the content of heavy metals and metalloids on roads with different traffic intensities have been determined. Road dust in Tyumen, like in most other cities on Earth, has an alkaline reaction, which is caused by the entry of carbonate microparticles. The total content of organic matter varies from 0.07 to $2.9 \%$, the largest amount of organic matter is noted on roads with low traffic intensity, which indicates the influence of soils. The particle size distribution is dominated by the PM fraction of 100-250 $\mu \mathrm{m}$. The content of finer particles (PM $<50 \mu \mathrm{m}$ ), which largely come from industrial plants, is low. Thus, the composition of road dust is formed mainly under the influence of traffic-related and soil erosion sources. The largest number of small particles (PM <2 and PM2-10) was observed on roads with medium traffic intensity. On roads with the most intensive traffic, blowing out small particles leads to a decrease in their proportion in the particle size distribution. The increased content of small particles on roads with medium traffic volumes leads to the fact that there is the highest concentration of pollutants.

Compared with the average content in the Earth's crust, Tyumen's road dust is enriched in $\mathrm{Ni}, \mathrm{Sb}, \mathrm{Cr}, \mathrm{Zn}, \mathrm{Co}$, $\mathrm{Cu}, \mathrm{Pb}, \mathrm{Cd}, \mathrm{W}$. More than $90 \%$ of $\mathrm{Ni}, \mathrm{Sb}, \mathrm{Cr}$ comes from anthropogenic sources. Dust collected on low-traffic roads contains less $\mathrm{Cr}, \mathrm{Ni}, \mathrm{Sb}, \mathrm{Bi}, \mathrm{Hg}$ than on medium-to-high traffic roads. The Mann-Whitney test showed a high degree of significance of differences $(p=0.01)$, which indicates a transport source of these elements.

Comparison of the obtained results with the data on the trace elements content in the road dust of other cities of the Earth showed that in Tyumen the road dust contains a lot of $\mathrm{Ni}, \mathrm{Cr}$, Co. The average concentration of $\mathrm{Ni}$ and $\mathrm{Cr}$ in the road dust of Tyumen is one order of magnitude higher than in other cities of the Earth. The high content of these metals is associated with the composition of local soils and roadways, abrasion of metal parts of machines. However, other trace elements that are considered indicators of anthropogenic impact $(\mathrm{Cu}, \mathrm{Cd}, \mathrm{Pb})$ are contained in Tyumen's road dust in moderate amounts. Therefore, the value of the total pollution indicators (IPI, Zc) at most observation points corresponds to the average level.

\section{Declarations}


Ethics approval and consent to participate

Not applicable (this paper does not contain studies involving human participants, human data, or human tissue).

Consent for publication

Not applicable (this paper does not contain any individual person's data in any form).

Availability of data and materials

The datasets generated during and/or analyzed during the current study are available from the corresponding author on reasonable request.

Competing interests

The authors declare that they have no competing interests.

Funding

This research was funded by the Russian Foundation for Basic Research (project No 19-05-50062) and project no. 121041600045-8 of RAS Siberian Branch

Authors' contributions

Conceptualization and methodology, D.M; Field sample acquisition, R.P and D.U.; Writing - re-view \& editing, D.M., A.Z.; Visualization, R.P and D.U. All authors have read and agreed to the published version of the manuscript.

Acknowledgements

Special thanks to Mr. Vasiliy Karandashev for the element determination.

Corresponding author

Correspondence to Dmitriy Moskovchenko

\section{References}

1. Acosta JA, Faz A, Kalbitz K et al (2011) Heavy metal concentrations in particle size fractions from street dust of Murcia (Spain) as the basis for risk assessment. J Environ Monit 13:3087-3096

2. Adachi K, Tainosho Y (2004) Characterization of heavy metal particles embedded in tire dust. Environ. Int 30:1009-1017

3. Akhter MS, Al-Jowder O (1997) Heavy metal concentrations in sediments from the coast of Bahrain. Int $\mathrm{J}$ of Environmental Health Research 7(1):85-93. https://doi.org/10.1080/09603129774039 
4. Al-Awadhi JM, AlShuaibi AA (2013) Dust fallout in Kuwait city: deposition and characterization. Sci Total Environ 461:139-148. http://dx.doi.org/10.1016/j.scitotenv.2013.03.052

5. Al-Khashman OA (2007) Determination of metal accumulation in deposited street dusts in Amman, Jordan. Environ Geochem Health 29:1-10

6. Amato F, Pandolfi M, Viana M, Querol X, Alastuey A, Moreno T (2009) Spatial and chemical patterns of PM10 in road dust deposited in urban environment. Atmos Environ 43: 1650-1659.

7. Amato F, Cassee FR, Denier van der Gon HAC, Gehrig R, Gustafsson M, Hafner W. et al (2014) Urban air quality: The challenge of traffic non-exhaust emissions. J Hazard Mater 275:31-36.

8. Atiemo MS, Ofosu GF, Kuranchie-Mensah H, Tutu AO, Linda Palm NDM, Blankson SA (2011) Contamination assessment of heavy metals in road dust from selected roads in Accra, Ghana. Res $\mathrm{J}$ Environ Earth Sci 3(5):473-80.

9. Banerjee ADK. Heavy metal levels and solid phase speciation in street dust of Delhi,India (2003) Environ Pollut 123:95-105

10. Bi XY, Liang SY, Li XD (2013) Trace metals in soil, dust, and tree leaves of the urban environment, Guangzhou, China. Chinese Science Bulletin 58(2):222-230

11. Charron A, Harrison RM (2005) Fine (PM2.5) and coarse (PM2.5-10) particulate matter on a heavily trafficked London highway: sources and processes. Environ Sci Technol. Oct 15 39(20):7768-76 http://doi: 10.1021/es050462i. PMID: 16295835

12. Chen J, Wang W, Liu H, Ren L (2012) Determination of road dust loadings and chemical characteristics using resuspension. Environ Monit Assess 184:1693-1709 https://doi.org/10.1007/s10661-011-2071-1

13. Chow J, Watson J, Lu Z (1996) Descriptive analysis of PM (2.5) and PM(10) at regionally representative locations during SJVAQS/AUSPEX. Atmos Environ 12: 2079-2112

14. Christoforidis A, Stamatis N (2009) Heavy metal contamination in street dust and roadside soil along the major national road in Kavala's region, Greece. Geoderma 15:257-263 https://doi.org/10.1016/j.geoderma.2009.04.016

15. GOST 23740-2016. Soils. Methods of Laboratory Determination of Organic Composition; Standartinform: Moscow, Russia, 2019. (in Russian)

16. Dall'Osto M, Beddows DC, Gietl JK, Olatunbosun OA, Yang X, Harrison RM (2014) Characteristics of tyre dust in polluted air: Studies by single particle mass spectrometry (ATOFMS). Atmos Environ 94: 224-230 https://doi.org/10.1016/j.atmosenv.2014.05.026

17. De Miguel E, Llamas JF, Chacón E, Berg T, Larssen S, Royset O, Vadset M (1997) Origin and patterns of distribution of trace elements in street dust. Unleaded petrol and urban lead. Atmos Environ 31:27332740 https://doi.org/10.1016/S1352-2310(97)00101-5

18. Denier van der Gon HAC, Gerlofs-Nijland ME, Gehrig R, Gustafsson M, Janssen N, Harrison RM et al. (2013) The policy relevance of wear emissions from road transport, now and in the future-an international workshop report and consensus statement. J. Air Waste Manag 63:136-149 https://doi.org/10.1080/10962247.2012.741055 
19. Ellis JB, Revitt DM (1982) Incidence of heavy metals in street surface sediments: solubility and grain size studies. Water Air Soil Pollut17:87 -100. https://doi.org/10.1007/BF00164094

20. Ferguson JE, Kim N (1991) Trace elements in street and house dusts source and speciation. Sci Total Environ100:125-150 https://doi.org/10.1016/0048-9697(91)90376-P

21. Ferreira-Baptista L, De Miguel E (2005) Geochemistry and risk assessment of street dust in Luanda, Angola: A tropical urban environment. Atmos Environ 39: 4501-4512.

https://doi:10.1016/j.atmosenv.2005.03.026

22. Gabarron M, Faz A, Acosta JA (2017) Effect of different industrial activities on heavy metal concentrations and chemical distribution in topsoil and road dust. Environ Earth Sci 76 (3): 129 https://doi:10.1007/s12665-017-6449-4

23. Germanova TV, Kernozhitskaya AF (2014) Environmental assessment of the transport system in urbanized territories (on the example of Tyumen City). Izvestiya Samarskogo nauchnogo tsentra Rossiiskoi akademii nauk 16(1):1713-1716. (in Russian)

24. Guo L, Lyu Y, Yang Y (2017) Concentrations and chemical forms of heavy metals in the bulk atmospheric deposition of Beijing, China. Environ Sci Pollut Res 24:27356-27365. https://doi.org/10.1007/s11356-017-0324-4.

25. Guseinov AN, Karabatov PA, Lysova GV, Panfilova LA (1997) Ecological and geochemical monitoring in the territory around the thermal power plants of Tyumen City. Teploenergetika 12:31-36. (in Russian)

26. Hakanson L (1980) An ecological risk index for aquatic pollution control, a sedimentological approach. Water Res 14: 975-1001 http://dx.doi.org/10.1016/0043-1354(80)90143-8

27. Han L, Zhuang G, Cheng S, Wang Y, Li J (2007) Characteristics of re-suspended road dust and its impact on the atmospheric environment in Beijing. Atmos Environ 41:7485-7499

28. Hjortenkrans D, Bergback B, Haggerud A (2006) New metal emission patterns in road traffic environments. Environ Monit Assess 117:85-98 https://doi.org/10.1007/s10661-006-7706-2

29. Hu X, Zhang Y, Luo J, Wang T, Lian H, Ding Z (2011) Bioaccessibility and health risk of arsenic, mercury and other metals in urban street dusts from a mega-city, Nanjing, China. Environmental Pollution 159:1215-1221 https://doi.org/10.1016/j.envpol.2011.01.037

30. Irvine KN, Perrelli MF, Ngoen-klan R, Droppo IG (2009) Metal levels in street sediment from an industrial city: spatial trends, chemical fractionation, and management implications, J. Soils Sedim 9:328-341 https://doi.org/10.1007/s11368-009-0098-5

31. Jadoon WA, Khpalwak W, Chidya RCG et al (2018) Evaluation of Levels, Sources and Health Hazards of Road-Dust Associated Toxic Metals in Jalalabad and Kabul Cities, Afghanistan. Arch Environ Contam Toxicol 74, 32-45 https://doi.org/10.1007/s00244-017-0475-9

32. Kabata-Pendias A (2011) Trace elements in soils and plants: Fourth edition. CRC Press, Boca Raton, London, New York, Washington, D.C.

33. Kasimov NS, Kosheleva NE, Vlasov DV, Terskaya EV (2012) Geochemistry of snow cover in the Eastern District of Moscow. Bulletin of Moscow University. Series 5. Geography 4: 14-25. (in Russian). 
34. Kasimov NS, Bityukova VR, Malkhazova SM, Kosheleva NE, Nikiforova EM, Shartova NV, Vlasov DV, Timonin SA, Krainov VN (2014) Regions and cities of Russia: the integrated assessment of the environment. IP Filimonov MV, Moscow. (in Russian)

35. Kasimov NS, Bezberdaya LA, Vlasov DV, Lychagin MY (2019a) Metals, metalloids, and benzo[a]pyrene in PM10 particles of soils and road dust of Alushta City. Eurasian Soil Science 52(12):1608-1621 https://doi.org/10.1134/S1064229319120068

36. Kasimov NS, Kosheleva NE, Vlasov DV, Nabelkina KS, Ryzhov AV. Physicochemical properties of road dust in Moscow (2019b) Geography, Environment, Sustainability 12(4):96-113 https://doi.org/10.24057/2071-9388-2019-55

37. Kaygorodov RV, Tiunova MI, Druzshinina AA (2009) Polluting substances in a dust of travellers of parts and in wood vegetation of roadside strips of a city zone. Vestnik Permskogo Universiteta, Seriya: Biologiya 10(36): 141-146 (in Russian)

38. Kim W, Doh SJ, Park YH, Yun ST (2007) Two-year magnetic monitoring in conjunction with geochemical and electron microscopic data of roadside dust in Seoul, Korea. Atmos Environ 41(35):7627-7641 https://doi.org/10.1016/j.atmosenv.2007.05.050

39. Kjelgaard J. Sharratt B, Sundram I, Lamb B, Claiborn C, Saxton K, Chandler D (2004) PM10 emission from agricultural soils on the Columbia Plateau: comparison of dynamic and time-integrated fieldscale measurements and entrainment mechanisms Agric For Meteorol 125(3-4):259-277 https://doi.org/10.1016/j.agrformet.2004.04.004

40. Konstantinova E, Minkina T, Sushkova S, Konstantinov A, Rajput VD, Sherstnev Al (2019) Urban soil geochemistry of an intensively developing Siberian city: A case study of Tyumen, Russia. J Environ Manag 239(1): 366-375 https://doi.org/10.1016/j.jenvman.2019.03.095

41. Konstantinova E., Minkina T, Konstantinov A, Sushkova S, Antonenko E, Kurasova A, Loiko S (2020) Pollution status and human health risk assessment of potentially toxic elements and polycyclic aromatic hydrocarbons in urban street dust of Tyumen city, Russia. Environ Geochem Health 1-24 https://doi.org/10.1007/s10653-020-00692-2

42. Kosheleva NE, Vlasov DV, Korlyakov ID, Kasimov NS (2018) Contamination of urban soils with heavy metals in Moscow as affected by building development. Sci Total Environ 636:854-863 https://doi.org/10.1016/j.scitotenv.2018.04.308

43. Krest'yannikova EV, Kozlova VV, Larina NS, Larin SI (2015) Chemical and environmental assessment of lead pollution in the atmosphere of the city of Tyumen. Izvestiya Samarskogo nauchnogo tsentra Rossiiskoi akademii nauk 17(5-2):679-684. (In Russian)

44. Krupnova TG, Rakova OV, Gavrilkina SV, Antoshkina EG, Baranov EO, Yakimova ON (2020) Road dust trace elements contamination, sources, dispersed composition, and human health risk in Chelyabinsk, Russia. 261. 127799.doi.org/10.1016/j.chemosphere.2020.127799

45. Ladonin DV, Plyaskina OV (2009) Isotopic composition of lead in soils and street dust in the Southeastern administrative district of Moscow. Eurasian Soil Science 42(1): 93-104. https://doi.org/10.1134/S1064229309010128 
46. Landing WM, Caffrey JM, Nolek SD, Gosnell KJ, Parker WC (2010) Atmospheric wet deposition of mercury and other trace elements in Pensacola, Florida. Atmos Chem Phys 10:4867-4877 https://doi.org/10.5194/acp-10-4867-2010

47. Li K, Liang T, Wang L, Yang Z (2015) Contamination and health risk assessment of heavy metals in road dust in Bayan Obo Mining Region in Inner Mongolia, North China. J Geogr Sci 25(12):1439-1451. https://doi.org/10.1007/s11442-015-1244-1

48. Li F, Zhang J, Huang J. et al (2016) Heavy metals in road dust from Xiandao District, Changsha City, China: characteristics, health risk assessment, and integrated source identification. Environ Sci Pollut Res 23:13100-13113 https://doi.org/10.1007/s11356-016-6458-y

49. Lindgren A (1996) Asphalt Wear and Pollution Transport. The Science of the Total Environment, 189190:281-286 http://dx.doi.org/10.1016/0048-9697(96)05220-5

50. Liu CW, Lin KH, Kuo YM (2003) Application of factor analysis in the assessment of groundwater quality in a Blackfoot disease area in Taiwan. Sci Total Environ 313:77-89

51. Lu X, Wang L, Lei K, Huang J, Zhai Y (2009) Contamination assessment of copper, lead, zinc, manganese and nickel in street dust of Baoji, NW China. J Hazard Mater 161:1058-1062

52. Moskovchenko DV (1998) Oil and gas production and the environment: ecological and geochemical analysis of the Tyumen region.: Nauka, Sib.predpriyatie RAN Novosibirsk (In Russian)

53. Muller G (1969) Index of geoaccumulation in sediments of the Rhine River. Geojournal 2:108-118

54. Murakami M, Nakajima F, Furumai H, Tomiyasu B, Owari M (2007) Identification of particles containing chromium and lead in road dust and soakaway sediment by electron probe microanalyser.

Chemosphere 67(10):2000-2010

55. Nazzal Y, Rosen MA, Al-Rawabden AM (2013) Assessment of metal pollution in urban road dusts from selected highways of the Greater Toronto Area in Canada. Environ Monit Assess 185:1847-1858

56. Nikiforova EM, Kosheleva NE, Kasimov NS (2011) Analysis of pollution with heavy metals in soils of the Eastern district of Moscow (based on data collected during 1989-2010). Inzhenernaya Geologia 3:34-45 (in Russian)

57. Nriagu JO (1996) A history of global metal pollution. Science 272(5259):223-223 https://doi.org/10.1126/science.272.5259.223

58. Nriagu JO, Pacyna J (1988) Quantitative assessment of worldwide contamination of air, water and soil by trace metals. Nature 333:134 - 139

59. Padoan E, Romè C, Ajmone-Marsan F (2017) Bioaccessibility and size distribution of metals in road dust and roadside soils along a peri-urban transect. Sci Total Environ 601-602:89-98 https://doi.org/10.1016/j.scitotenv.2017.05.180

60. Pan H, Lu X, Lei K (2017) A comprehensive analysis of heavy metals in urban road dust of Xi'an, China: contamination, source apportionment and spatial distribution. Sci Total Environ 609:1361-1369 https://doi.org/10.1016/j.scitotenv.2017.08.004

61. Pozhitkov RY (2020) The content of suspended particles PM2.5 and PM10 in the surface layer of the atmosphere of Tyumen in June 2020. Atmospheric and Oceanic Optics 33(12):913- 
917 https://doi.org/10.15372/A0020201202 (in Russian)

62. Rajaram BS, Suryawanshi PV, Bhanarkar AD, Rao CVC (2014) Heavy metals contamination in road dust in Delhi city, India. Environ Earth Sci 72:3929-3938 https://doi.org/10.1007/s12665-014-3281-y

63. Rasmussen P, Subramanian K, Jessiman B (2001) A multi-element profile of house dust in relation to exterior dust and soils in the city of Ottawa, Canada. Sci Total Environ 267:125-140 https://doi.org/1010.1016/S0048-9697(00)00775-0

64. Reference Book on the USSR Climate. Series 2. Issue 17. Tyumen and Omsk regions (1998). Gidrometeoizdat Publ, S.-Petersburg (In Russian).

65. Robertson DJ, Taylor KG, Hoon SR (2003) Geochemical and mineral magnetic characterisation of urban sediment particulates, Manchester, UK. Appl Geochem 18:269-282 https://doi.org/10.1016/S0883-2927(02)00125-7

66. Rudnick RL, Gao S (2003) Composition of the continental crust. In: Rudnick RL, editor. Treatise on geochemistry. Vol. 3: The Crust. Elsevier Science pp 1-64 https://doi.org/10.1016/B0-08-0437516/03016-4

67. Saet YE, Revich BA, Yanin EP et al (1990) Geochemistry of the environment. Nedra Publ, Moscow (In Russian)

68. Salmanighabeshi S, Palomo-Marín MR, Bernalte E, Rueda-Holgado F, Miró-Rodríguez C, Fadic-Ruiz X, Vidal-Cortez V, Cereceda-Balic F, Pinilla-Gil E (2015) Long-term assessment of ecological risk from deposition of elemental pollutants in the vicinity of the industrial area of Puchuncaví-Ventanas, central Chile. Sci. Total Environ 527-528:335-343. https://doi.org/10.1016/j.scitotenv.2015.05.010

69. Shi G, Chen Z, Bi C. et al (2011) A comparative study of health risk of potentially toxic metals in urban and suburban road dust in the most populated city of China. Atmos Environ 45(3):764-771 https://doi.org/10.1016/j.atmosenv.2010.08.039

70. Singh AK (2011) Elemental chemistry and geochemical partitioning of heavy metals in road dust from Dhanbad and Bokaro regions, India. Environ Earth Sci 62:1447-1459 https://doi.org/10.1007/s12665010-0630-3

71. Sizov O, Konstantinov A, Volvakh A, Molodkov A (2020) Timing and sedimentary record of late quaternary fluvio-aeolian successions of the Tura-Pyshma interfluve (SW Western Siberia, Russia). Geosciences 10:396 https://doi.org/10.3390/geosciences10100396

72. Skipin LN, Berseneva AG (2014) Ecological assessment of urbanozems on the example of the territories of the city of Tyumen. Agrarnyi vestnik Urala 2(120):71-73 (in Russian)

73. Sutherland RA, Tack FM, Ziegler AD (2012) Road-deposited sediments in an urban environment: a first look at sequentially extracted element loads in grain size fractions. J Hazard Mater 225-226:54-62. https://doi.org/10.1016/j.jhazmat.2012.04.066Sutherland, 2000

74. Tager IB (2005) Health effects of aerosols: mechanisms and epidemiology. In: Ruzer LS, Harley NH (Eds) Aerosols Handbook: Measurement, dosimetry, and health effects, CRC Press, Boca Raton, pp 619-696 
75. Tume P, Roca N, Rubio R, King R, Bech J (2018) An assessment of the potentially hazardous element contamination in urban soils of Arica, Chile, J Geochem. Explor. 184(Part B):345-357 http://dx.doi.org/10.1016/j.gexplo.2016.09.011

76. Varrica D, Dongarra G, Sabatino G, Monna F (2003) Inorganic geochemistry of roadway dust from the metropolitan area of Palermo, Italy. Environ Geol 44:222-230 https://doi.org/10.1007/s00254-0020748-z

77. Viana M, Querol X, Alastuey A, Gil Jl, Menendez M (2006) Identification of PM sources by principal component analysis (PCA) coupled with wind direction data. Chemosphere 65:2411-2418 https://doi.org/10.1016/j.chemosphere.2006.04.060

78. Vlasov DV, Kasimov NS, Kosheleva NE (2015) Geochemistry of the road dust in the Eastern district of Moscow. Vestnik Moskovskogo Universiteta, Geografiya 1: 23-33 (in Russian)

79. Wei B, Jiang F, Li X, Mu S (2010) Heavy metal induced ecological risk in the city of Urumqi, NW China. Environ Monit Assess 160:33 https://doi.org/10.1007/s10661-008-0655-1

80. Yang T, Liu Q, Zeng Q, Chan, L (2010) Anthropogenic magnetic particles and heavy metals in the road dust: magnetic identification and its implications. Atmos Environ 44:1175-1185 doi:10.1016/j.atmosenv.2009.12.028

81. Yisa J, Jacob JO, Onoyima CC (2011) Identification of sources of heavy metals pollution in road deposited sediments using multivariate statistical analysis. J Emerg Trends Eng Appl Sci 2(4):658663

82. Yongming H, Peixuan D, Junji C, Posmentier ES (2006) Multivariate analysis of heavy metal contamination in urban dusts of Xi'an, Central China. Sci Total Environ, 355:176-186 https://doi.org/10.1016/j.scitotenv.2005.02.026

83. Zaytseva NV, May IV, Maks AA, Zagorodnov SY (2013) Analysis of the dispersion and component composition of the dust for the assessment of the exposure to the population in the areas of influence of industrial emissions of stationary source. Hyg Sanit 5:19-23.

84. Zhang MK, Wang H (2009) Concentrations and chemical forms of potentially toxic metals in roaddeposited sediments from different zones of Hangzhou, China. J Environ Sci 21:625-631

85. Zhang M, Lu X, Chen H, Gao P, Fu Y (2015) Multi-element characterization and source identification of trace metal in road dust from an industrial city in semi-humid area of Northwest China. J Radioanal Nucl Chem 303:637-646 https://doi.org/10.1007/s10967-014-3300-1

86. Žibret G, Rokavec D (2010) Household dust and street sediment as an indicator of recent heavy metals in atmospheric emissions: a case study on a previously heavily contaminated area. Environ Earth Sci 61:443-453 https://doi.org/10.1007/s12665-009-0356-2.

\section{Figures}




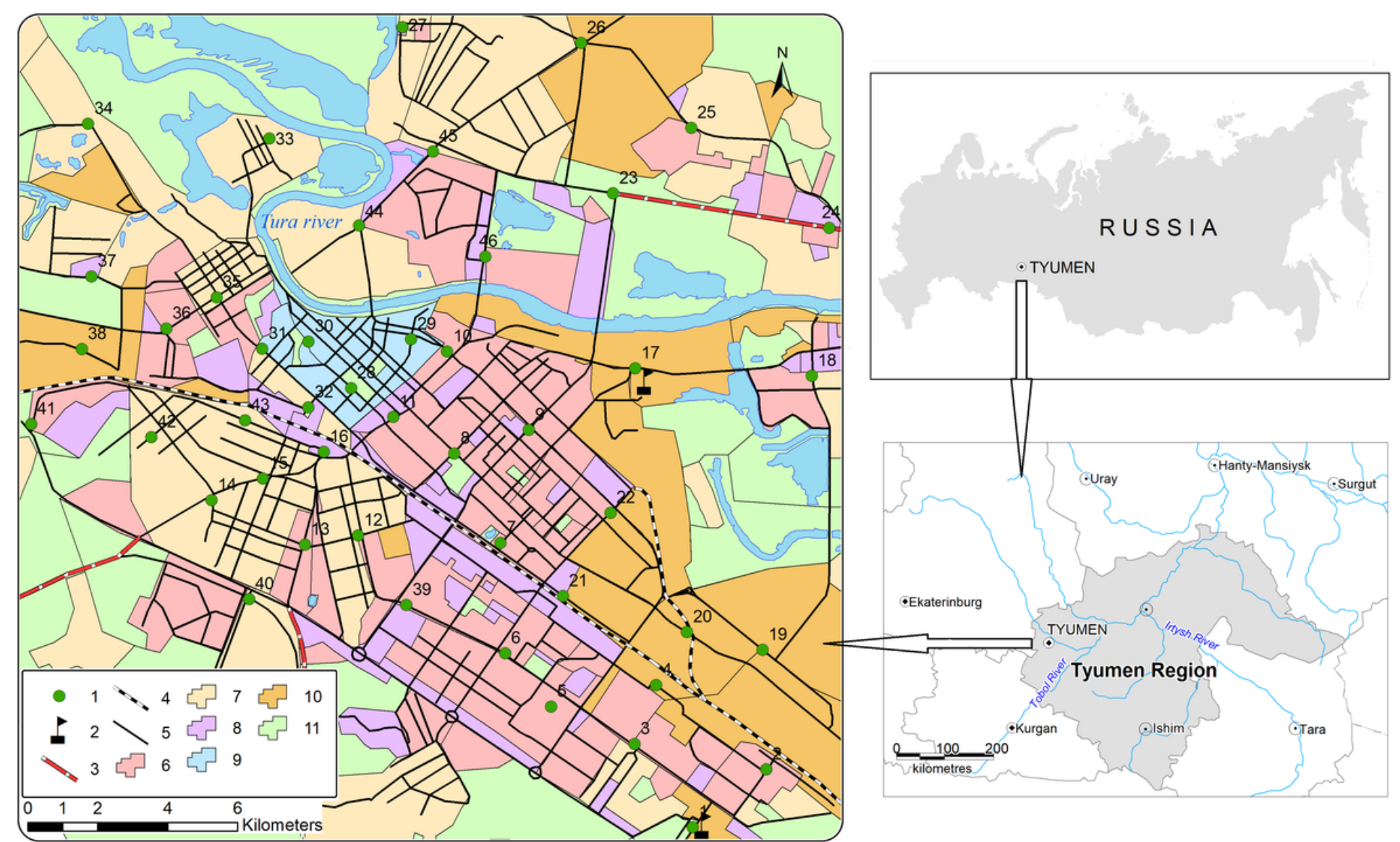

\section{Figure 1}

Sampling sites and land-use areas within the city of Tyumen, Russia: 1 - sampling sites; 2 - power plants; 3 - main federal roads; 4 - trans-siberian railway; 5 - main city roads; 6 - high-rise residential area; 7 - lowrise residential area; 8 - modern business zones; 9 - historical center; 10 - industrial zones; 11 recreation and unbuilt areas 


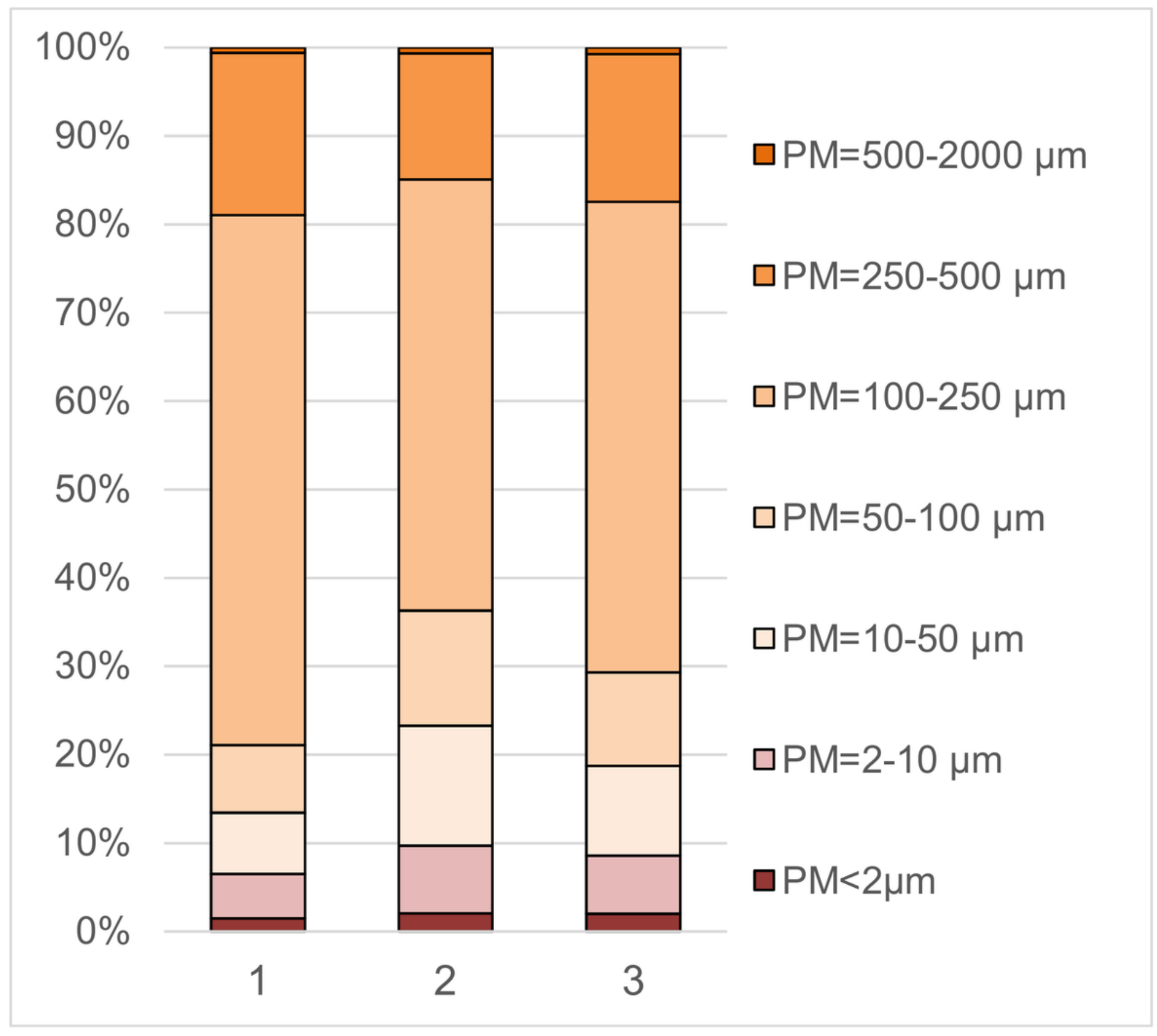

Figure 2

The proportion of particle size fractions in road dust. traffic intensity: 1 - low, 2 - moderate, 3 - high 
$\%$

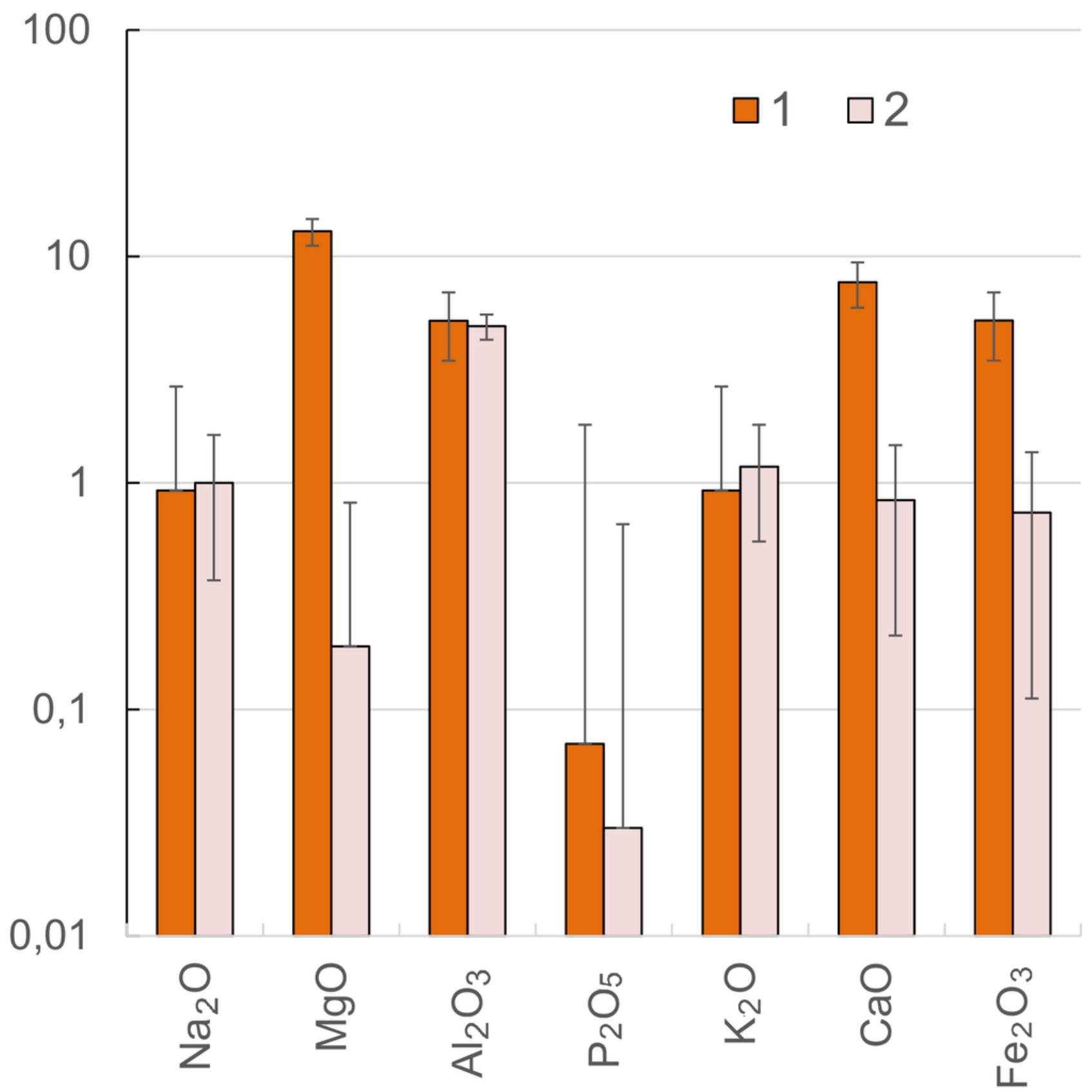

Figure 3

Major elements mean concentrations (in weight percent oxide) in Tyumen road dust (this study, $n=50$ ) and Quaternary aeolian deposits (Sizov et al. 2020) 1 - road dust 2 - aeolian deposits 


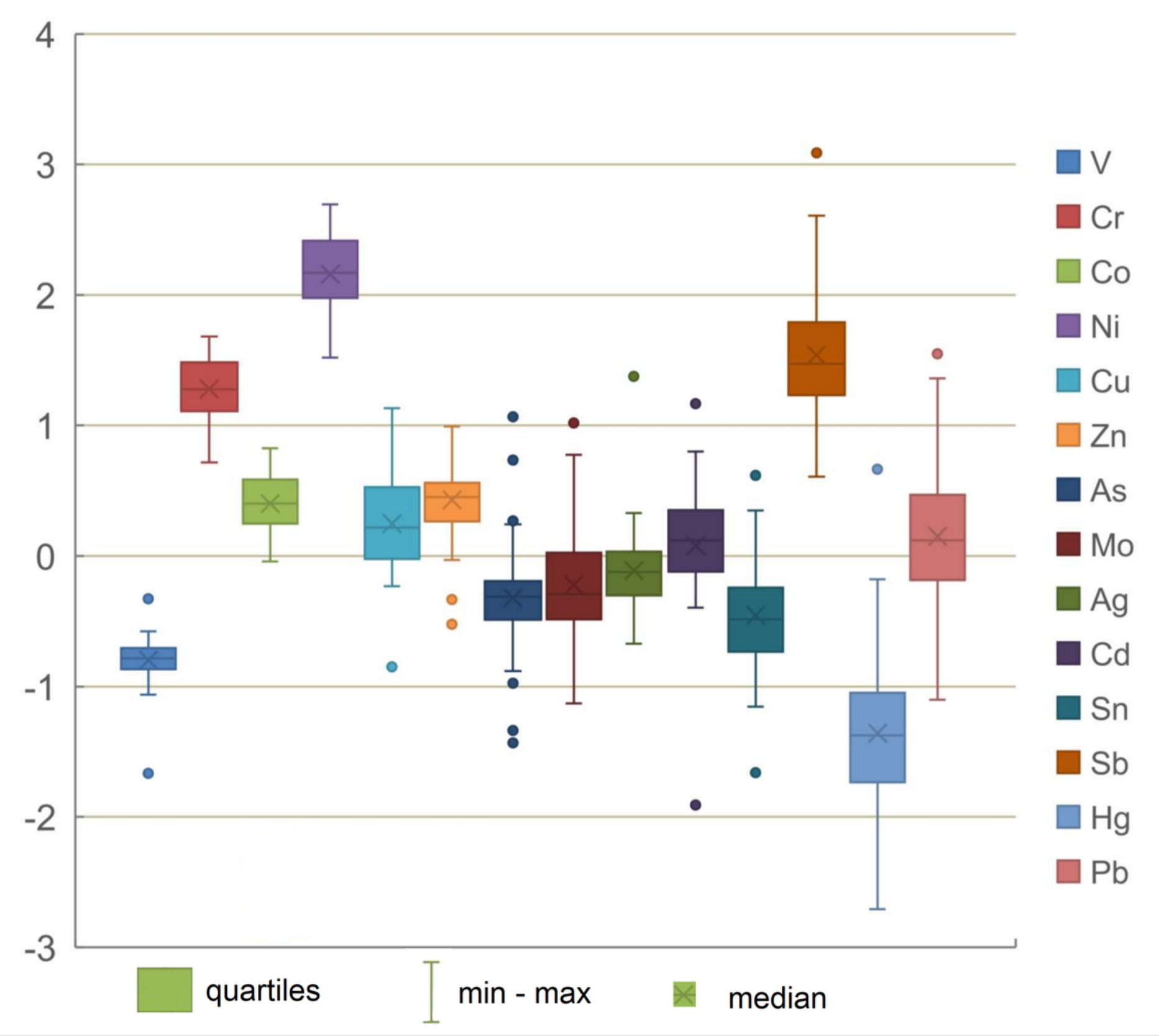

Figure 4

Boxplots of the geoaccumulation index (Igeo) for the 14 heavy metals and metalloids in road dusts of Tyumen. The horizontal line within the box represents the median value. The box represent the 25 th and 75th quantiles. The middle line represent the $95 \%$ confidence interval. The data point not in the range of whiskers is considered as outliers. EF calculations showed that Tyumen's road dust is very high enriched in $\mathrm{Ni}$ and significantly enriched in $\mathrm{Cr}$ and $\mathrm{Sb}$. $70 \%$ of the samples are significantly enriched in $\mathrm{Zn}, 62 \%$ in $\mathrm{Co}$, $42 \%$ in $\mathrm{Cu}, 34 \%$ in $\mathrm{Pb}$, and $26 \%$ in $\mathrm{Cd}$. Moderate enrichment of road dust was noted for $\mathrm{Mo}, \mathrm{As}, \mathrm{W}, \mathrm{Sn}, \mathrm{Bi}, \mathrm{W}$. The remaining 30 elements are classified as "deficiency to minimal enrichment" (EF <2).

\section{Supplementary Files}


This is a list of supplementary files associated with this preprint. Click to download.

- TableSM1.docx

- TableSM2.docx 